\title{
Quantitative Easing and Long-Term Yields in Small Open Economies
}

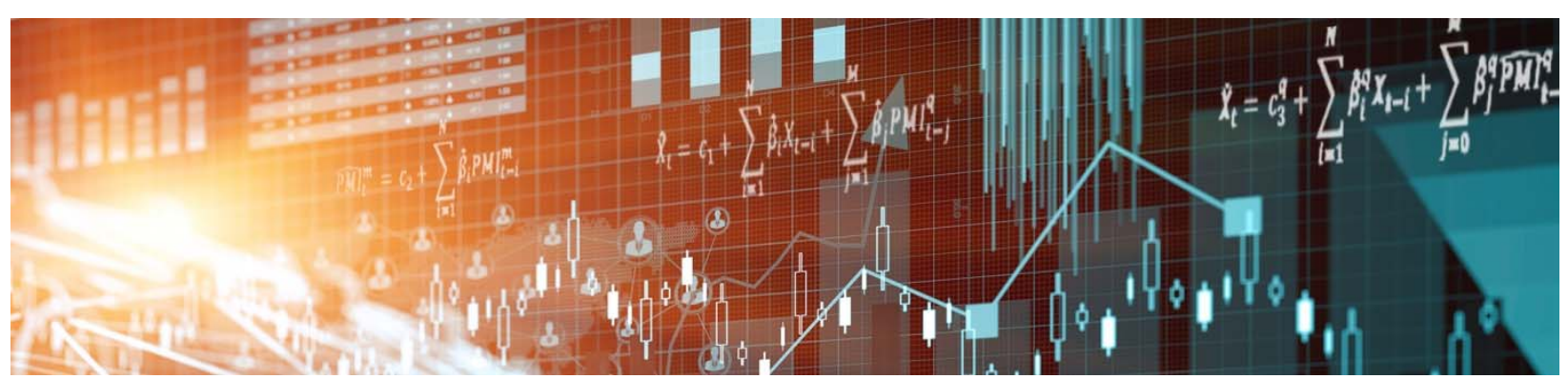

by Antonio Diez de los Rios and Maral Shamloo 
Bank of Canada Staff Working Paper 2017-26

July 2017

\title{
Quantitative Easing and Long-Term Yields in Small Open Economies
}

by

Antonio Diez de los Rios ${ }^{1}$ and Maral Shamloo ${ }^{2}$

\author{
1Financial Markets Department \\ Bank of Canada \\ Ottawa, Ontario, Canada K1A 0G9 \\ adiez@bankofcanada.ca \\ ${ }^{2}$ Monetary and Capital Markets Department \\ International Monetary Fund \\ 700 19th Street N.W., Washington, DC 20431 \\ mshamloo@imf.org
}




\section{Acknowledgements}

We are very grateful to Greg Bauer and Jonathan Witmer for extensive conversations on the effect of unconventional monetary policies in small open economies. We would also like to thank Jens Christensen and Matt Roberts-Sklar as well as seminar participants at the Bank of Canada Conference on "Unconventional Monetary Policies: A Small Open Economy Perspective," and the IMF's Policy Forum for their useful comments suggestions. The views expressed in this paper are those of the authors and do not necessarily reflect those of the Bank of Canada nor the International Monetary Fund. 


\begin{abstract}
We compare the Federal Reserve's asset purchase programs with those implemented by the Bank of England and the Swedish Riksbank, and the Swiss National Bank's reserve expansion program. We decompose government bond yields into (i) an expectations component, (ii) a global term premium and (iii) a country-specific term premium to analyze two-day changes in 10-year yields around announcement dates. We find that, in contrast to the Federal Reserve's asset purchases, the programs implemented in these smaller economies have not been able to affect the global term premium and, consequently, their effectiveness in lowering long-term yields has been limited.
\end{abstract}

Bank topics: Financial markets; Interest rates; Monetary policy

JEL codes: E43, E52, E58, G12

\title{
Résumé
}

Nous comparons les programmes d'achat d'actifs de la Réserve fédérale avec ceux mis en œuvre par la Banque d'Angleterre et la Banque de Suède, et avec le programme d'expansion monétaire de la Banque nationale suisse. Nous décomposons les rendements des obligations d'État en i) une composante des anticipations, ii) une prime de terme mondiale et iii) une prime de terme propre au pays pour analyser l'évolution sur deux jours du rendement des obligations à dix ans aux alentours des dates d'annonce. Nous constatons que, contrairement aux achats d'actifs effectués par la Réserve fédérale, les programmes mis en œuvre dans ces économies plus petites ne sont pas parvenus à influer sur la prime de terme mondiale et, par conséquent, leur efficacité pour réduire les rendements à long terme a été limitée.

Sujets : Marchés financiers ; Taux d'intérêt ; Politique monétaire

Codes JEL : E43, E52, E58, G12 


\section{Non-Technical Summary}

In the aftermath of the 2007-08 financial crisis, many central banks - including the Federal Reserve, the European Central Bank, the Bank of Japan, and also those in smaller economies such as the Bank of England (BoE), the Riksbank and the Swiss National Bank (SNB) - have undertaken large-scale asset purchase (LSAP) programs or quantitative easing (QE) with the aim of lowering long-term yields and thus encouraging consumption and investment and, ultimately, spurring economic activity.

Central bank asset purchases lower long-term yields through at least two main channels. First, asset purchases might contain news about future short-term rates. To the extent that the announcement of an asset purchase program might lead market participants to revise their expectations of future short-term rates, long-term rates will also fall. Changes in long-term rates due to revised expectations are referred to as the signaling channel of central bank purchases.

Second, asset purchases can affect long-term yields by reducing the amount of longer-term government securities in private sector portfolios. Specifically, as central banks reduce the supply of longer-term government securities, investors need to rebalance their portfolios towards assets of similar characteristics (i.e., maturity, credit, etc.). This tends to bid up not only the price of the purchased security (i.e., lower its yield) but also the price of close substitutes. This is referred to as the portfolio balance channel of central bank asset purchases.

In this paper, we shed light on the effectiveness of asset purchase programs in small open economies. We do this by studying the responses of long-term yields on government securities to the BoE's and Riksbank's asset purchase announcements, as well as the SNB's reserve expansion. In addition, we also study the responses of long-term yields to the Federal Reserve's LSAP program, as this provides a natural benchmark against which we can measure the effectiveness of the asset purchase programs implemented in other countries. Using an eventstudy methodology, we quantify the importance of the signaling and portfolio balance channels by decomposing observed two-day changes in 10-year yields around central bank announcements of asset purchases into their expectations and term premium components, respectively. Furthermore, we also separate changes in term premia into a global and a countryspecific component using a one-factor model, given that our estimates of term premia are highly correlated across countries, thus decomposing portfolio balance effects into global and purely domestic channels.

Our analysis suggests that, with the exception of a few announcements, the changes in long-term rates around asset purchase announcements by the BoE, the Riksbank and the SNB are substantially smaller than the changes observed after the first round of asset purchases implemented by the Federal Reserve. Specifically, our results suggest that these programs do not affect the global term premium component of the yields. While QE programs in small open economies have involved the purchase of a large proportion of their domestic government bond markets, they are relatively small once we account for the size of the pool of substitutable assets. Consequently, their effectiveness in reducing long-term interest rates has been limited. 


\section{INTRODUCTION}

Having reached the effective lower bound on nominal policy rates in the aftermath of the 2007-08 financial crisis, several central banks have adopted other monetary policy tools to further ease their policy stance. In particular, many central banks - the Federal Reserve, the European Central Bank (ECB), the Bank of Japan, but also central banks in smaller economies such as the Bank of England (BoE), the Riksbank and the Swiss National Bank (SNB) - have undertaken large-scale asset purchase (LSAP) programs or quantitative easing (QE) with the aim of lowering long-term yields and thus encouraging consumption and investment and, ultimately, spurring economic activity. ${ }^{1}$

While the initial assessment regarding the effectiveness of these unconventional monetary policies has been largely positive, studies have focused mainly on the impact of the Federal Reserve's LSAP program (see, e.g., Gagnon et al., 2011, Christensen and Rudebusch, 2012, and Bauer and Rudebusch, 2014, among others). The question therefore remains as to whether the lessons learned from the U.S. experience are applicable for the central banks of small open economies. In this paper, we attempt to answer this question by analyzing the channels through which these programs affect the stance of monetary policy, thereby evaluating the effectiveness of QE programs in small open economies such as the United Kingdom, Sweden and Switzerland.

Central bank asset purchases lower long-term yields via at least two main channels. First, asset purchases might contain news about future short-term rates. To the extent that the announcement of an asset purchase program might lead market participants to revise their expected path of future short-term rates, long-term rates will also fall. Changes in long rates due to a revision in expectations are referred to as the signaling channel of central bank purchases.

Second, asset purchases can affect long-term yields by reducing the amount of longer-term government securities in private sector portfolios (see Bernanke, 2011, Kohn, 2009, Williams, 2011, and Yellen, 2011). Specifically, as central banks reduce the supply of longer-term government securities, investors need to rebalance their portfolios towards assets of similar characteristics (i.e., maturity, credit, etc.). This tends to bid up not only the price of the purchased security (i.e., lower its yield) but also the price of close substitutes. ${ }^{2}$ This is referred to as the portfolio balance channel of central bank asset purchases.

\footnotetext{
${ }^{1}$ In the remainder of the paper we will use the terms LSAP and QE interchangeably.

2 The dependence of longer-term yields on the private sector holdings of longer-term assets was the subject of a substantial literature in the 1950s and 1960s. See, for example, Culbertson, (1957), Modigliani and Sutch (1966) and Wallace (1967). More recently, Vayanos and Vila (2009) and Greenwood and Vayanos (2014) have proposed modern "preferred-habitat" models where shocks to the supply of a particular bond can affect the full-term structure of interest rates.
} 
In a world with global capital markets, the set of substitutable securities potentially includes foreign bonds. Consequently, some of the portfolio rebalancing occurs at the international portfolio level, i.e., towards the now relatively underpriced foreign debt of similar credit quality. For example, Bauer and Neely (2014) and Neely (2015) find evidence that the effects of the Federal Reserve's asset purchase program spilled over to international bond yields.

This international spillover depends on two factors: (i) the size of asset purchases relative to the size of the pool of substitutable assets, and (ii) the degree of substitutability of domestic and foreign bonds. Put differently, international investors in the bonds issued by small open economies are highly price sensitive because of the existence of a large set of similar (i.e., highly substitutable) assets. In contrast, if U.S. Treasury bonds are special in certain ways and cannot be substituted easily (i.e., because of the reserve currency status of the dollar), the price-taking element is to a large extent eliminated.

The focus of this paper is to understand the differences in the way QE affects long-term yields in small open economies (as opposed to a large country like the United States) and the extent to which these differences might limit the effectiveness of asset purchases in small open economies. Specifically, we study the responses of long-term yields on government securities to the BoE's and the Riksbank's asset purchase announcements, and the SNB's reserve expansion program. In addition, we also study the responses of long-term yields to the Federal Reserve's LSAP program, as this provides a natural benchmark against which we can measure the effectiveness of the asset purchase programs implemented in other countries. Specifically, using an event-study methodology, we quantify the importance of the signaling and portfolio balance channels by decomposing observed two-day changes in 10-year yields around central bank announcements of asset purchases into their expectations and term premium components, respectively. Importantly, and consistent with Ilmanen (1995), Perignon, Smith and Villa (2007), Hellerstein (2011), Dahlquist and Hasseltoft (2013) and Bauer and Diez de los Rios (2012), among others, we find that our estimates of term premia are highly correlated across countries. For this reason, we further separate changes in term premia into a global and a country-specific component using a one-factor model.

Our analysis suggests that, in general, the changes in long-term rates around asset purchase announcements by the BoE, the Riksbank and the SNB are substantially smaller than the changes observed after the first round of asset purchases implemented by the Federal Reserve. Specifically, our results suggest that these programs do not affect the global term premium component of the yields. While QE programs in small open economies have involved the purchase of a large proportion of their domestic government bond markets (close to 30 and 40 per cent of the stock of outstanding nominal government debt in the United Kingdom and Sweden), they are relatively small once we take into account the size of the pool of 
substitutable assets. ${ }^{3}$ Consequently, their effectiveness in reducing long-term interest rates has been limited.

However, our analysis should not be interpreted as evidence that asset purchases are not expansionary in small open economies. Rather, asset purchases do not seem to be expansionary through the lowering of long-term yields, as is the case in larger economies. For example, expected returns on international investments depend both on the expected asset return in local currency and on the expected change in the exchange rate. Consequently, exchange rates could be affected as well. Glick and Leduc $(2012,2015)$ and Neely $(2015)$, for example, find that the U.S. dollar depreciated around the Federal Reserve's asset purchase announcements. In this way, by putting downward pressure on the exchange rate, asset purchases can also be stimulative by encouraging an increase in net exports (i.e., an exchange rate channel). However, the analysis in this paper abstracts from the transmission of QE through exchange rates, and we leave the study of this channel for further research.

The remainder of this paper is organized as follows: Section 2 discusses the channels of transmission of asset purchases to long-term interest rates. Section 3 presents our empirical methodology to decompose long-term interest rates into an expectations and a term premium component. Section 4 analyzes the changes in the 10-year yield and its components in a twoday window around the announcement of asset purchases by the Federal Reserve, the BoE, the Riksbank and the SNB's reserve expansion. Section 5 concludes.

\section{SIGNALING AND PORTFOLIO BALANCE CHANNELS IN AN INTERNATIONAL SETUP}

As noted in the literature, central bank asset purchases can potentially lower bond yields through mainly two channels: (i) a signalling channel and (ii) a portfolio balance channel (see, e.g., Gagnon et al., 2011, Christensen and Rudebusch, 2012, Bauer and Rudebusch, 2014, Joyce et al., 2011, Bauer and Neely, 2014, among many others). ${ }^{4}$ In order to distinguish between these two channels, it is useful to define the expectations component and the term premium of the yield of a long-term zero-coupon bond, a 10-year bond in our example, as:

$$
y_{j, t}^{(10)}=\frac{1}{10} \sum_{j=0}^{9} E_{t} r_{j, t+j}+t p_{j, t}^{(10)}
$$

where $y_{j, t}^{(10)}$ is the yield at time $t$ on a $n$-year zero-coupon bond of country $j .^{5}$ The first term is the average of the expected one-year interest rate over the next 10 years. In our model, we

\footnotetext{
${ }^{3}$ For example, by the end of 2015, the sizes of the stock of outstanding nominal government debt in the U.K. and Sweden were approximately 20 per cent and 1 per cent, respectively, of the size of U.S. Treasury bond market.

${ }^{4} \mathrm{QE}$ can potentially affect asset prices through other channels as well, for example, by affecting liquidity and credit risk. See, for example, Krishnamurthy and Vissing-Jorgensen (2011) and Christensen and Gillian (2016).

${ }^{5} \mathrm{~A}$ zero-coupon bond is a claim that sells at a price today and yields a payment of $\$ 1$ at maturity. Investors thus earn a yield on the bond by buying at a price less than $\$ 1$ today and holding the bond to maturity. The yield on the zero-coupon bond can be calculated from prices of regular coupon-bearing bonds observed in the market.
} 
use the one-year interest rate in country $j$ as a proxy for that country's policy rate (i.e., $\left.r_{j, t}=y_{j, t}^{(1)}\right){ }^{6}$ The second term is a time-varying term-structure risk premium that represents the extra compensation that investors require for interest rate risk associated with holding a 10-year bond.

\section{A. Signaling Channel}

The signaling channel recognizes that asset purchases contain news about the expected path of future short-term rates. To the extent that the announcement of an asset purchase program leads market participants to revise their expectations of future short-term rates, it can affect long-term rates. This mechanism is captured by the first component of long-term interest rates in equation (1). Specifically, the signaling channel captures the effect on interest rates of any new information that economic agents might learn from the central bank announcement regarding the future path of short-term rates either directly (i.e., in the form of explicit forward guidance) or indirectly (i.e., information regarding the central bank's views on current or future economic conditions, changes in the central bank's reaction function, and/or changes in the policy objectives $)^{7}$

More important for analyzing the international effects of QE, the announcement of an asset purchase program by a large central bank such as the Federal Reserve can trigger market participants to revise their expectations regarding future policy rates in other countries. This could be the case because (i) central banks often respond similarly to common global economic and financial shocks, or (ii) some central banks might be concerned with excessive volatility in foreign exchange markets and therefore adjust their monetary policy stance in response to the major changes in foreign monetary policy. As pointed out by Bauer and Neely (2014), who study spillover effects from the Federal Reserve's asset purchase announcements to international yields, such monetary policy correlations give rise to an international signaling channel. Below, we extend the work by Bauer and Neely (2014) by examining whether asset purchases by central banks in small open economies can also lead to revisions in the expected monetary policy path for other central banks around the world.

\section{B. Portfolio Balance Channel}

The portfolio balance channel captures the impact on bond prices that occurs when private sector investors adjust their portfolio positions in response to a reduction in the supply of a specific security, for instance, longer-term government bonds (see, e.g., Tobin 1961 and 1963). Such effects are captured by the second component of long-term interest rates in equation (1).

\footnotetext{
${ }^{6}$ A country's one-year rate can be viewed as being closely related to the current (short-term) policy rate that is targeted by that country's central bank, as well as to the expectations of near-term policy moves.

${ }^{7}$ An example of direct information was the Federal Reserve's December 2008 Federal Open Market Committee (FOMC) press release, which stated that "economic conditions [were] likely to warrant exceptionally low levels of the federal funds rate for some time."
} 
As central bank asset purchases reduce the supply of longer-term government securities, investors rebalance their portfolios towards assets of similar characteristics (e.g., maturity, credit and quality). This not only tends to bid up the price of the purchased bond (i.e., lower its yield) but also bids up the price of a wider set of assets. This result cannot be delivered in the standard representative agent models, because in such models there is no distinction between government and private asset holdings. Consequently, there is no role in such models for the supply of long-term bonds in determining bond prices (see, among others, Gagnon et al., 2011, and Krishnamurthy and Vissing-Jorgensen, 2011).

On the other hand, in a model with incomplete markets and imperfect substitutability between different assets, a QE program can affect asset prices by changing the relative supply of different assets. For example, Vayanos and Vila (2009) and Greenwood and Vayanos (2014) offer such a model, where a group of investors prefer a certain maturity of bonds ("preferred habitat"), while risk-averse arbitrageurs integrate the market by trading across maturities. In this model, a reduction in the supply of a particular security creates a shortage that increases its price. Consequently, arbitrageurs sell the "scarce" security, given that it is now relatively overpriced, and rebalance their portfolio towards other substitutable bonds that are now relatively underpriced. As the markets converge to a new equilibrium, arbitrageurs spread the scarcity created by the central bank in a particular bond across different maturities and to other bonds with similar characteristics. ${ }^{8}$

In a world with global capital markets, the set of substitutable securities includes foreign bonds; as a consequence, some of the portfolio rebalancing occurs at the international portfolio level (i.e., towards the now relatively underpriced foreign debt of similar characteristics). Indeed, Bauer and Neely (2014) find evidence of such international spillover effects following the Federal Reserve's asset purchase program.

This international rebalancing implies that the size of an asset purchase program relative to the size of the pool of substitutable securities should also matter in a world with integrated capital markets. Put differently, an issuer in a small open economy may be, by and large, a price taker in global capital markets given that a large set of highly substitutable bonds is available. In principle, this could limit the effectiveness of asset purchase programs in lowering interest rates in small open economies in contrast to the case of the United States, (where U.S. Treasuries benefit from specialness given the reserve-currency status of the dollar) or the eurozone (where euro-denominated bonds may enjoy better liquidity or higher

\footnotetext{
${ }^{8}$ Christensen and Krogstrup (2016a) have pointed out that alternative portfolio balance effects also arise due to the increase in the supply of central bank reserves that accompanies a typical large-scale asset purchase program. The logic relies on the fact that only banks can hold reserves, whereas central banks can purchase assets from banks and non-banks. As a result, the banks may end up with portfolio durations that are shorter than optimal, inducing them to buy long-term bonds. They refer to this as a reserve-induced portfolio balance channel. In reality, the distinction between the reserve-induced portfolio balance channel and the traditional, supply-induced portfolio balance channel is unobservable. Therefore, what we measure as the portfolio balance channel does not distinguish between the two mechanisms.
} 
acceptance as collateral than bonds issued in other jurisdictions). We study the validity of this hypothesis below.

\section{Event-Study Methodology}

Consistent with the literature on the evaluation of central bank asset purchases, we quantify the importance of the signaling and portfolio balance channels by measuring the respective contribution of the expectations and term premium components to the observed two-day changes in 10-year yields around central bank announcements of asset purchases. ${ }^{9}$ As in Bauer and Rudebusch (2014), we focus on announcements rather than asset purchases themselves, given that forward-looking investors will react immediately to news of future purchases. Thus, credible asset purchase announcements should lower the term premium component of long-term yields immediately.

We still note that an event-study approach is, of course, an imperfect methodology and entails many assumptions. First, it assumes that the announcement is entirely unanticipated and that its full effect on yields takes place on the day of the announcement. This is likely to underestimate the asset-price response for later asset purchase announcements, given that market participants might have formed expectations of increasing bond purchases prior to the

official announcements. ${ }^{10}$ Second, it also assumes that there are no market failures that would prevent the full price effect from taking hold at the time of announcement before any purchases have actually taken place. Third, in using a two-day window in our event study, we are implicitly assuming that this is short enough to abstract from any other event that could affect long-term yields.

As noted by Bauer and Rudebusch (2014) and Joyce et al. (2011), among others, estimated changes in the expectations component are likely to be only a lower bound for the contribution of the signaling channel to changes in the long-term yields because of secondround effects. First, a successful monetary policy action aimed at easing financial conditions and stimulating future growth will raise short-rate expectations for the more distant future, counteracting the decrease in the expectations component due to signaling effects. Second, signaling near-zero policy rates for an extended period of time tends to lower interest rate risk and the term premium, even without any portfolio balance effect.

\section{EMPIRICAL METHODOLOGY}

As discussed earlier, our empirical methodology allows us to consider the effect of QE announcements on various components of the long-term yields. To do so, we follow a two-

\footnotetext{
${ }^{9}$ Our database suffers from the same problem as in Christensen and Krogstrup (2016a) in the sense that we do not know exactly when, during the day, the yield data we use were collected. In this regard, a longer window is needed to guarantee that the announcement is reflected in all the yields across all the countries in our sample.

${ }^{10}$ Alternatively, we could try to estimate the surprise content of asset purchase programs directly. See, for example, Wright (2012) and Glick and Leduc (2012), who analyze the Federal Reserve's LSAP program, and Rogers, Scotti and Wright (2014) for a cross-country comparison of such shocks.
} 
step strategy. First, we use a term-structure model to decompose the yields into their expectation and term-premia components (see equation 1). Then, we further decompose the term premium in each country into a global and a country-specific component, by extracting the first principal component of an international cross-section of estimated term premia.

\section{A. Data}

Our data set consists of end-of-month observations over the period January 1995 to June 2016 of the term structures of zero-coupon bond yields for the United States, the United Kingdom, Germany, Canada, Sweden and Switzerland. We consider all annual maturities from 1 to 10 years.

To capture the cross-sectional variation of bond yields, we focus on the first three principal components of each of the yield curves in each country. These three factors explain 99.9 per cent of the variation of yields in each country and have the traditional interpretation of level, slope and curvature (Litterman and Scheinkman, 1991).

\section{B. Estimating Term Premia}

The average path of the short-term interest rate can be forecasted by estimating a collection of individual or vector autoregression (VAR) models on the level, slope and curvature factors for each of the individual countries' yield curves:

$$
\boldsymbol{f}_{j, t}-\boldsymbol{\mu}_{j}=\boldsymbol{\Phi}_{j}\left(\boldsymbol{f}_{j, t-1}-\boldsymbol{\mu}_{j}\right)+\boldsymbol{\varepsilon}_{j, t},
$$

where $\boldsymbol{f}_{j, t}=\boldsymbol{P}_{j}^{\prime} \boldsymbol{y}_{j, t}$ and $\boldsymbol{y}_{j, t}$ is a vector that stacks all the yields in a given country, $\boldsymbol{P}_{j}^{\prime}$ is a full-rank matrix such that $\boldsymbol{f}_{j, t}$ coincides with the first three principal components of the crosssection of yields in country $j, \boldsymbol{\mu}_{j}$ is the unconditional mean of $\boldsymbol{f}_{j, t}$ and $\boldsymbol{\varepsilon}_{j, t} \sim \operatorname{iid} N\left(\mathbf{0}, \boldsymbol{\Sigma}_{j}\right)$.

The expectations component of the $n$-year yield would then be obtained as follows: First, the loadings of the short-term rates are estimated by regressing the one-year yield $r_{j, t}=y_{j, t}^{(1)}$ on a constant and the three principal components, $\boldsymbol{f}_{j, t}$ :

$$
r_{j, t}=\delta_{0, j}+\boldsymbol{\delta}_{j}^{\prime} \boldsymbol{f}_{j, t}
$$

Second, the $h$-step-ahead forecast of $\boldsymbol{f}_{j, t}$ given the time $t$ information set implied by the VAR model in equation (2) is:

$$
E_{t} \boldsymbol{f}_{j, t+h}=\left(\boldsymbol{I}-\boldsymbol{\Phi}_{j}^{h}\right) \boldsymbol{\mu}_{j}+\boldsymbol{\Phi}_{j}^{h} \boldsymbol{f}_{j, t} .
$$

Thus, combining equations (3) and (4), we have that the expectations component of the $n$-year yield is given by the following expression:

$$
\frac{1}{n} \sum_{i=0}^{n-1} E_{t} r_{j, t+i}=\delta_{0, j}+\boldsymbol{\delta}_{j}^{\prime} \boldsymbol{\mu}_{j}+\left(\boldsymbol{I}-\boldsymbol{\Phi}_{j}\right)^{-1}\left(\boldsymbol{I}-\boldsymbol{\Phi}_{j}^{h}\right)\left(\boldsymbol{f}_{j, t}-\boldsymbol{\mu}_{j}\right) .
$$

Therefore, given estimates of $\delta_{0, j}, \boldsymbol{\delta}_{j}^{\prime}, \boldsymbol{\mu}_{j}$ and $\boldsymbol{\Phi}_{j}$ (which, in principle, could be obtained using ordinary least squares regressions), one can define the term premium of the 10 -year country $j$ 
zero-coupon bond as the residual of the observed 10-year bond yield from the forecast average path of the short-term rate:

$$
t p_{j, t}^{(n)}=y_{t}^{(n)}-\delta_{0, j}-\boldsymbol{\delta}_{j}^{\prime} \boldsymbol{\mu}_{j}-\left(\boldsymbol{I}-\boldsymbol{\Phi}_{j}\right)^{-1}\left(\boldsymbol{I}-\boldsymbol{\Phi}_{j}^{h}\right)\left(\boldsymbol{f}_{j, t}-\boldsymbol{\mu}_{j}\right) .
$$

\section{A Near Cointegrated Panel Vector Autoregression}

Estimating the term premium component as the residual of the observed 10-year bond yield from the VAR-implied expectations component involves mainly two problems. First, the high persistence of interest rates makes them very hard to predict in the medium and long run. This leads to large statistical and specification uncertainty around these estimates and, consequently, around the estimated term premia (see, e.g., Cochrane and Piazzesi, 2008). Second, VAR estimates tend to suffer from the well-known problem that ordinary least squares (OLS) estimates of autoregressive parameters tend to underestimate the persistence of the system in finite samples. Consequently, expected long-run future short rates tend to be almost constant, which implies that most of the variability in the long end of the yield curve tends to be attributed to movements in risk premia rather than monetary policy expectations (see, among others, Bauer, Rudebusch and $\mathrm{Wu}, 2012$ ).

We deal with these two problems in the following way: First, we obtain more precise estimates of the dynamics of the factors by estimating the VAR model in panel format. Specifically, we pool the observations for the countries in our sample while allowing for country-specific constant terms. In other words, we impose cross-country homogeneity on the slope coefficients of the VAR models:

$$
\boldsymbol{\Phi}_{j}=\boldsymbol{\Phi} \quad \forall j,
$$

Figure 1 shows the estimated principal components in each country and across tenors. As the figure shows, the dynamics of the components, particularly the level factor, are similar in different countries, providing support for the assumption above. In fact, we are not able to reject the hypothesis of cross-country homogeneity at conventional levels.

In addition, we also note that the factor loadings are very close in different countries (see Figure 2). As a result, we compute level, slope and curvature factors in each country by using the average of the relevant factor loading across countries: $\boldsymbol{f}_{j, t}=\boldsymbol{P}^{\prime} \boldsymbol{y}_{j, t}$ where $\boldsymbol{P}=\frac{1}{J} \sum_{j=1}^{J} \boldsymbol{P}_{j}$.

Second, we impose that the level of interest rates in country $j$ follows a highly persistent autonomous first-order autoregressive (AR) process (i.e., neither slope nor curvature factors have predictable power over changes in the level of interest rates). ${ }^{11}$ This assumption can be justified on the basis that the level factor of the yield curve is usually identified with the

\footnotetext{
${ }^{11}$ In the absence of these restrictions, we find the change in the expectations and term premium components around several announcement dates to move in opposing directions (while theory suggests that both the signaling and the portfolio balance effects should pull bond yields in the same direction).
} 
central bank's implicit inflation target as perceived by private agents (see, e.g., the macrofinance term structure model of Rudebusch and $\mathrm{Wu}, 2008)$, which is usually modeled as a highly persistent autonomous AR(1) process itself (see, e.g., Kozicki and Tinsley, 2001). We expect that, by tightly constraining the dynamics of the factors across countries, we are able to further reduce the sampling uncertainty that is likely influencing the forecasts of interest rates. In fact, Duffee (2011) shows that a model similar to ours where the level follows a random walk process (i.e., a model where the autocorrelation coefficient for the level factor is one) does well in out-of-sample forecasting of U.S. Treasury yields. ${ }^{12}$

While restricting the largest root of the VAR to be equal to one, as in Duffee (2011), should help both reduce estimation uncertainty and avoid the downward bias in the estimated persistence of the system, we find that such an assumption usually leads to decompositions of the yield curve where the estimated term premia play almost no role in explaining the variability in the long end of the yield curve. For this reason, we depart slightly from this approach and model the level factors of interest rates as a near-unit root process instead. ${ }^{13}$

Specifically, we tackle the persistence bias in our system by considering a weighted average of the estimates of the panel VAR model where the level follows a stationary AR process, and those of a panel VAR where the level factors follow a random walk. Such a model combination approach has been shown by Hansen (2010) and Jardet, Monfort and Pegoraro $(2011,2013)$ to perform well for time series with high persistence. ${ }^{14}$

To summarize, our restricted near-cointegrated panel VAR model can be expressed as:

$$
\begin{gathered}
\left(\begin{array}{c}
l_{j, t}-\mu_{l, j} \\
s_{j, t}-\mu_{s, j} \\
c_{j, t}-\mu_{c, j}
\end{array}\right)=\left(\begin{array}{ccc}
\tilde{\phi}_{11} & 0 & 0 \\
0 & \phi_{22} & \phi_{23} \\
0 & \phi_{32} & \phi_{33}
\end{array}\right)\left(\begin{array}{c}
l_{j, t-1}-\mu_{l, j} \\
s_{j, t-1}-\mu_{s, j} \\
c_{j, t-1}-\mu_{c, j}
\end{array}\right)+\left(\begin{array}{c}
\varepsilon_{j, l, t} \\
\varepsilon_{j, s, t} \\
\varepsilon_{j, c, t}
\end{array}\right), \\
\boldsymbol{f}_{j, t}-\boldsymbol{\mu}_{j}=\boldsymbol{\Phi}\left(\boldsymbol{f}_{j, t-1}-\boldsymbol{\mu}_{j}\right)+\boldsymbol{\varepsilon}_{j, t},
\end{gathered}
$$

for $j=1, \ldots, J$ where $\tilde{\phi}_{11}=\omega \times 1+(1-\omega) \phi_{11}$, where $\omega$ is the weight of the unit root model and $\phi_{11}$ is the unrestricted autoregressive parameter for the level factor. Note that when the weight $\omega$ is arbitrarily close to one, the first row of the autocorrelation matrix implies that the level factors behave as near random walks. Finally, we do not assume any particular structure for the cross-correlation of the error terms across countries.

\footnotetext{
${ }^{12} \mathrm{We}$ also note that modeling the level factor as an AR process is consistent with the preferred specifications of the term structure models estimated in Christensen and Rudebusch (2011) for the case of the U.S. and U.K. yield curves.

13 This leads to a model where there is a common near random walk variable (i.e., the level factor) driving the yield curve in each country, and hence the use of the "near-cointegration" terminology.

${ }^{14}$ Alternatively, we could have followed Bauer, Rudebusch and Wu (2012) by correcting the bias using bootstrap methods. However, we find the bias-corrected estimates lead to a system with explosive roots that requires the use of the stationary adjustment of Kilian (1998). Importantly, such an adjustment requires a judgement call on how close to one the largest eigenvalue of the system needs to be. For this reason, we felt that averaging between the unit root and the stationary model was, in our case, a cleaner way to document our judgement calls.
} 


\section{Estimation}

For simplicity, we focus on a model for the factors in deviation from their sample means. Specifically, we calibrate $\tilde{\phi}_{11}$ such that the impulse response at the five-year horizon for the response of the level factor to a level shock is 0.60 , which is in line with the estimated persistence of the system in Bauer, Rudebusch and $\mathrm{Wu}, 2012,2014) .{ }^{15}$ This implies $\widetilde{\phi}_{11}=0.996$.

We estimate the remaining parameters of the panel VAR model using a minimum distance (MD) estimator. Note that our panel VAR model can be thought of as a larger VAR in the whole set of slopes and curvatures where exclusion restrictions on the parameters have been imposed. This larger-scale VAR can be expressed as:

$$
\begin{aligned}
\left(\begin{array}{l}
\tilde{\boldsymbol{f}}_{1, t}-\widetilde{\boldsymbol{\mu}}_{1} \\
\tilde{\boldsymbol{f}}_{2, t}-\widetilde{\boldsymbol{\mu}}_{2} \\
\vdots \\
\tilde{\boldsymbol{f}}_{J, t}-\widetilde{\boldsymbol{\mu}}_{J}
\end{array}\right)= & \left(\begin{array}{cccc}
\boldsymbol{A}_{11} & \boldsymbol{A}_{12} & \cdots & \boldsymbol{A}_{1 J} \\
\boldsymbol{A}_{21} & \boldsymbol{A}_{22} & \cdots & \boldsymbol{A}_{2 J} \\
\vdots & \vdots & \ddots & \vdots \\
\boldsymbol{A}_{J 1} & \boldsymbol{A}_{J 2} & \cdots & \boldsymbol{A}_{J J}
\end{array}\right)\left(\begin{array}{c}
\tilde{\boldsymbol{f}}_{1, t-1}-\widetilde{\boldsymbol{\mu}}_{1} \\
\tilde{\boldsymbol{f}}_{2, t-1}-\widetilde{\boldsymbol{\mu}}_{2} \\
\vdots \\
\tilde{\boldsymbol{f}}_{J, t-1}-\widetilde{\boldsymbol{\mu}}_{J}
\end{array}\right)+\left(\begin{array}{c}
\boldsymbol{u}_{1, t} \\
\boldsymbol{u}_{2, t} \\
\vdots \\
\boldsymbol{u}_{J, t}
\end{array}\right), \\
& \left(\tilde{\boldsymbol{f}}_{t}-\tilde{\boldsymbol{\mu}}\right)=\boldsymbol{A}(\boldsymbol{\beta})\left(\tilde{\boldsymbol{f}}_{t-1}-\tilde{\boldsymbol{\mu}}\right)+\boldsymbol{u}_{\boldsymbol{t}},
\end{aligned}
$$

where $\tilde{\boldsymbol{f}}_{j, t}=\left(s_{j, t}, c_{j, t}\right)^{\prime}, \boldsymbol{\mu}_{j}=\left(\mu_{s, j}, \mu_{c, j}\right)$ and $\boldsymbol{\beta}=\left(\phi_{22}, \phi_{32}, \phi_{23}, \phi_{33}\right)^{\prime}$. Specifically, crosscountry homogeneity can be written as the following restrictions on the matrix $\boldsymbol{A}(\boldsymbol{\beta})$ :

$$
\operatorname{vec}[\boldsymbol{A}(\boldsymbol{\beta})]=\boldsymbol{G} \boldsymbol{\beta},
$$

for an appropriately chosen full rank matrix $\boldsymbol{G}$.

The idea of the MD estimator is to obtain an estimate of the unrestricted parameter coefficients of the larger VAR (i.e., $\widehat{\boldsymbol{A}}$ ) using OLS regressions, and then infer the parameters of the panel VAR by forcing the cross-country homogeneity restrictions in equation (13), evaluated at the unrestricted larger VAR parameters, to be as close as possible to zero in the metric defined by a suitable weighting matrix $\boldsymbol{W}$ :

$$
\begin{gathered}
\widehat{\boldsymbol{\beta}}=\arg \min T[\operatorname{vec}(\widehat{\boldsymbol{A}})-\boldsymbol{G} \boldsymbol{\beta}]^{\prime} \boldsymbol{W}[\operatorname{vec}(\widehat{\boldsymbol{A}})-\boldsymbol{G} \boldsymbol{\beta}], \\
\widehat{\boldsymbol{\beta}}=\left(\boldsymbol{G}^{\prime} \boldsymbol{W} \boldsymbol{G}\right)^{-1} \boldsymbol{G}^{\prime} \boldsymbol{W} \operatorname{vec}(\widehat{\boldsymbol{A}}),
\end{gathered}
$$

where $T$ is the sample size.

\footnotetext{
15 This is equivalent to putting an 81.6 per cent weight in the unit root model, given that the unconstrained estimate (using the minimum distance approach detailed below) of $\phi_{11}$ is 0.977 . Our results are qualitatively similar to those that use other weight choices that differ from the ones reported in this paper in the following way: weights closer to one give more importance to the signaling channel, and weights closer to zero give more importance to the portfolio balance channel (consistent with the intuition provided by Bauer, Rudebusch and $\mathrm{Wu}, 2012$ ).
} 
As in the case of the generalized method of moments estimation, (asymptotic) efficiency - in the sense that the difference between the asymptotic variance of the resulting MD estimator and another MD estimator based on any other quadratic form in the same distance function is negative semidefinite - gains can be achieved by selecting an appropriate weighting matrix. Specifically, we use the optimal weighting matrix, which, in our context, is the inverse of the asymptotic covariance of $\operatorname{vec}(\widehat{\boldsymbol{A}}) .{ }^{16}$ Further, the optimized value of the MD criterion function also has an asymptotic $\chi^{2}$ distribution with degrees of freedom equal to the number of overidentifying restrictions, which we use to test the restrictions implied by our model (i.e., cross-country homogeneity).

Finally, $\delta_{0, j}$ and $\boldsymbol{\delta}_{j}^{\prime}$ are estimated by an OLS regression of the one-year yield on a constant and the country $j$ 's factors. ${ }^{17}$

\section{E. Global Term Premia}

Figure 3 displays our estimates for the decomposition of 10-year yields into the expectations and term premia for each of the six countries in our study. Figure 4 shows that our term premia estimates for all the countries are highly correlated across countries. Specifically, the average correlation across term premia estimates is 0.70 for the whole sample and increases to 0.85 in the post-2007 sample. This high correlation in the term premium component across countries is consistent with Rey's $(2013,2016)$ assertion of the existence of a global financial cycle in which the prices of risky assets around the world have an important common component (see, e.g., Miranda-Agrippino and Rey, 2012).

Given this large correlation among the cross-country term premia, we use a one-factor model to decompose changes in the term premia into a global and a country-specific component. Specifically, we estimate the following model by OLS:

$$
t p_{j, t}^{(10)}=\beta_{j} g t p_{j, t}^{(10)}+c t p_{j, t}^{(10)}
$$

where $g t p_{j, t}^{(10)}$ is the first principal component of the cross-section of (10-year) term premia across countries, and $c t p_{j, t}^{(10)}$ is the residual resulting from this regression, which we interpret as the country-specific component of the term premium. We note that the $R^{2}$ resulting from

\footnotetext{
${ }^{16}$ Alternatively, our panel VAR estimation can be thought of as a seemingly unrelated regression (SUR) system in which the error terms are correlated. Specifically, it can be shown that under a suitably chosen weighting matrix (for instance, the one used in this paper), the MD estimator is identical to the Feasible Generalized Least Squares estimator of the parameters of the SUR system (see Moon and Perron, 2008).

${ }^{17}$ Note that unlike other papers in the literature (see, e.g., Bauer and Rudebusch, 2014, or Bauer and Neely, 2014), we do not impose a no-arbitrage restriction. However, our model can be considered as the reduced form of such a no-arbitrage model, and, consequently, such no-arbitrage restrictions can easily be imposed using the estimation method of Diez de los Rios (2015). However, in line with Joslin, Singleton and Zhu's (2011) theoretical result on the irrelevance of no-arbitrage restrictions for forecasting and the empirical results in Duffee (2011), we do not anticipate that imposing such restrictions will change our results.
} 
this regression are the highest for Canada and Germany (89.5 and 91.5 per cent, respectively) and the lowest for the United States and the United Kingdom (43.6 and 51.8 per cent). The $R^{2}$ for Switzerland and Sweden fall in between, with values of 77.6 and 74.1 per cent, respectively. ${ }^{18}$

We interpret these results as indirect evidence that the United States' and the United Kingdom's government bonds might be less substitutable than the bonds of the rest of the countries in our sample, given that a large proportion of the variation in the term premia in these two countries seems to be explained by their country-specific risks rather than global factors. This could partly be explained by the dominant role of the dollar (and to a lesser extent the British pound) in cross-border transactions and as a funding currency, and the position of New York and London in global financial markets (see, e.g., Goldberg and Tille, 2009, Gopinath, 2015, and Rey, 2016). This reserve currency status of the U.S. dollar makes it hard to substitute dollar-denominated assets with assets denominated in other currencies.

\section{Event Study of Central Bank Asset Purchase Programs}

In this section we use the estimates obtained using monthly data to analyze the response of long-term yields to the asset purchase programs announced by the Federal Reserve (section 4.A), the BoE (section 4.B) and the Swedish Riksbank (section 4.C) and the asset purchase and reserve expansion programs announced by the Swiss National Bank (section 4.D). Details on these announcements can be found in Tables 1, 3, 5 and 7, respectively.

We analyze two-day changes in the 10-year yield and its components around central bank asset purchase announcements. ${ }^{19}$ These decompositions can be found in Tables 2, 4, 6 and 8, respectively, which are all structured in the same way. Specifically, they show the changes in the 10-year yield between the previous day and the day after the announcement, as well as its decomposition into the expectations component and the global and country-specific components of the term premium. Panel A of each table presents the results for the yields of the country implementing the asset purchase program. Panel B presents the decomposition for the average of the yields for the rest of the countries (i.e., "rest of the world" results). We also follow Glick and Leduc (2012) in reporting $p$-values computed as the fraction of two-day

\footnotetext{
${ }^{18}$ Adding a second global factor increases the percentage explained of the term premia in the United States and the United Kingdom by global factors to 71.6 per cent and 85.1 per cent, respectively. However, the results reported below remain qualitatively the same. If anything, a model with two factors tends to give more importance to the global term premium component in explaining movements in cross-country term premia than a model with a single factor.

${ }^{19}$ For example, the term premium component can be expressed as an affine function of the factors: $t p_{j, t}^{(n)}=y_{j, t}^{(n)}-a_{j}^{(n)}-$ $\boldsymbol{b}_{j}^{(n) \prime} \boldsymbol{f}_{t}$ with $a_{j}^{(n)}$ and $\boldsymbol{b}_{j}^{(n)}$ computed according to equation (6). Thus we obtain a daily estimate of $\widehat{t p}_{j, t}^{(n)}$ using daily data on $y_{j, t}^{(n)}$ and $\boldsymbol{f}_{t}$ (which are readily available) by plugging in our implied estimates of $a_{j}^{(n)}$ and $\boldsymbol{b}_{j}^{(n)}$ into the previous expression.
} 
changes in the sample from January 1, 2000, to June 30, 2016, that were smaller than the change on the announcement day. ${ }^{20}$

\section{A. United States}

We start by analyzing the case of the Federal Reserve's LSAP programs. Even though this asset purchase program has been thoroughly studied (see, e.g., Gagnon et al., 2011, Krishnamurthy and Vissing-Jorgensen, 2011, Hamilton and Wu, 2012, and Glick and Leduc, 2015, among others), we use the lens of our model to revisit the effectiveness of the program in bringing down long-term interest rates for mainly two reasons. First, the Federal Reserve's LSAP program provides a natural benchmark against which we can measure the effectiveness of the asset purchase programs implemented in other (smaller) countries. Second, by decomposing term premia into global and country-specific components, we can provide additional insight into how the international portfolio balance channel operates.

\section{The Federal Reserve's QE Programs}

We start by briefly describing the three rounds of the asset purchases undertaken by the Federal Reserve between November 2008 and October 2014. The first round (QE1) was initiated in November 2008 when the Federal Reserve announced the purchase of up to $\$ 100$ billion of agency debt and up to $\$ 500$ billion of mortgage-backed securities. It was subsequently extended in March 2009 with the announcement of the additional purchase of up to $\$ 850$ billion of agency debt and $\$ 300$ billion in longer-dated Treasury securities.

In November 2010, the Federal Reserve announced yet another bond buying program (QE2), which involved buying an additional $\$ 600$ billion worth of longer-dated U.S. Treasury bonds by mid-2011. A third round of purchases was announced in September 2012 (QE3). In this case, the Federal Reserve announced it would spend close to $\$ 40$ billion per month in mortgage-backed securities. ${ }^{21}$

Specifically, we consider 14 asset purchase announcements related to the three rounds of asset purchases implemented by the Federal Reserve. These dates, and their specific details, are described in Table 1.

\footnotetext{
${ }^{20}$ Glick and Leduc (2012) compute two-sided $p$-values by focusing on the fraction of daily changes that were larger in absolute value than the change reported on the event day. We focus instead on one-sided $p$-values.

${ }^{21}$ In addition, the Federal Reserve initiated in September 2011 a maturity extension program (also known as Operation Twist), with the aim of increasing the average maturity of its treasury portfolio. In particular, the Federal Reserve purchased $\$ 400$ billion worth of U.S. Treasuries with maturities between 72 and 360 months, and sold off an equal amount of U.S. Treasuries with maturities in the 3- to 36-month range. Because of space limitations, and since this is not the main objective of our paper, we do not report results for this program.
} 


\section{Results}

We begin by considering the five LSAP announcements associated with the first round of the Federal Reserve's QE program, between November 2008 and March 2009, studied in Glick and Leduc (2012), Wright (2012) and Rogers, Scotti and Wright (2014). These dates are similar to those used by Gagnon et al. (2011), Bauer and Neely (2014), and Neely (2015) among others.

Two dates are particularly important in our study: November 25, 2008, which is the date of the Federal Reserve's first QE announcement, and March 18, 2009, which is the first announcement of the purchase of long-term Treasuries by the Federal Reserve. Specifically, the U.S. 10-year yield fell by 31 basis points (bps) when the Federal Reserve announced in November 2008 the purchase of agency debt and agency mortgage-backed securities even though the Fed did not announce the purchase of U.S. Treasury bonds (see Panel A of Table 2). Based on our decomposition of the yields, approximately half of this drop (15 bps) was due to a fall in term premium in the U.S. 10-year bond yield, split between a drop in the global ( 9 bps) and country-specific ( 6 bps) term premium components. The expectations component also fell as the QE announcement was interpreted as a signal of an imminent rate cut of the federal funds rate (as indeed happened when the fed funds rate was cut from 50 bps to a range of 0 to $25 \mathrm{bps}$ at the December 2008 Federal Open Market Committee, FOMC, meeting). Importantly, the Fed's November 2008 QE announcement also had an impact on the 10 -year yields of the rest of the countries, which dropped $11 \mathrm{bps}$ on average. This drop was mainly due to a fall in the global term premium component of $11 \mathrm{bps}$, which is consistent with the existence of an international portfolio balance channel (See Panel B, Table 2).

Later, on March 18, 2009, with the fed funds rate close to zero, the FOMC decided to broaden its purchase program to include longer-term Treasury securities. This led to a fall in U.S. 10 -year rates of $51 \mathrm{bps}$, and most of the fall was due to the country-specific term premium (22 bps). In addition, markets interpreted this announcement as a signal that the Fed would have to stay at its effective zero lower bound for longer than previously anticipated, and the expectations component fell by another 21 bps. As in the case with the November 2008 announcement, there were significant international portfolio balance spillovers to the other countries' interest rates, as the fall in the yields of the rest of the countries was similar in magnitude to the November 2008 announcement (10 bps, mainly due to the fall in the global term premium).

In general, the analysis of the five QE1 announcements reveals strong signaling effects for U.S. bond yields, a result consistent with Bauer and Rudebusch (2014). Specifically, the expectations component tends to capture between 20 and 50 per cent of the two-day change around the announcements. In addition, as confirmed by Bauer and Neely (2014), there are important international signaling effects. For example, almost 50 per cent of the fall long-term yields in the other five countries in our sample is due, on average, to the expectation component in these countries (see Panel B of Table 2). 
As for the contribution of the portfolio balance channel, we find that the main contributor to the fall in the term premium component, on the other hand, is the country-specific component (between 40 and 80 per cent). Even though it is small ( 5 bps on average), the fall in the global component of the U.S. term premium is also statistically significant. Indeed, the contribution of the country-specific component for the other countries is negligible, and almost all of the fall in their term premia seems to be explained by the global term premium component. Importantly, the results regarding the international portfolio balance channel are reminiscent of Rey's (2016) hypothesis that there is a global financial cycle largely driven by monetary policy decisions in the United States.

Regarding the second round of the Fed's QE program, we follow Glick and Leduc (2012), Wright (2012) and Rogers, Scotti and Wright (2014) and consider five dates that were announced in 2010. Finally, for the third round of QE, we select four dates in 2012 that include the dates analyzed in Bauer and Neely (2012) and Kozicki et al. (2015).

Importantly, our results suggest that, in contrast to the QE1 announcements, the fall in longterm yields in the United States tends to be smaller and less often statistically significant for the QE2 (three out of five announcements) and particularly QE3 (one out of four announcements). For example, the average fall in 10-year yields for the QE2 and QE3 programs is 8 and 0.2 bps for the case of the United States, and 3 and 0.2 bps for the average of the other five countries, respectively. Similarly, consistent with the evidence in Bauer and Neely (2014), we find no evidence of an international signaling nor a portfolio balance channel effect for the second and third rounds of the Fed's LSAP programs. These results are consistent with Haldane et al.'s (2016) hypothesis that the impact of QE programs seems to be larger the weaker the economy is and the more segmented financial markets are. The financial markets were more dislocated in the aftermath of the 2007-08 crisis than in 2010-12, and therefore the Fed's intervention helped alleviate the existing distortions.

\section{B. United Kingdom}

We now turn to the results regarding the response of long-term yields to the BoE's asset purchase announcements. We start by providing a quick summary of the BoE's QE program.

\section{The Bank of England's QE program}

The BoE's initial response to the financial crisis included cutting its policy rate from 5 per cent in October 2008 to 0.5 per cent in March 2009 and a wide range of measures directed towards supporting functioning of the financial market by providing liquidity support. ${ }^{22}$ To this end, the BoE set up the Asset Purchase Facility (APF) Fund on January 30, 2009—a subsidiary of the Bank of England, but indemnified by the Treasury in order to protect the Bank of England from any potential losses. The APF was authorized to purchase up to $£ 50$

\footnotetext{
${ }^{22}$ Further details of the BoE's QE program can be found in Cross, Fisher and Weeken (2010) and Joyce et al. (2011).
} 
billion of private sector assets (i.e., corporate bonds and commercial paper) financed by the issuance of short-term gilts in order to improve liquidity in impaired credit markets.

In fact, on March 5, 2009, the BoE Monetary Policy Commitee (MPC) decided, after cutting its policy rate from 1 per cent to 0.50 per cent, that further monetary stimulus was still needed. It thus expanded the APF's remit by (i) allowing purchases to be financed by issuing central bank reserves (instead of through the sale of short-term gilts) and (ii) expanding the range of eligible assets to include gilts. Specifically, the BoE's MPC announced that it would purchase $£ 75$ billion of assets over the subsequent three months and it would purchase gilts with a residual maturity of between 5 and 25 years. The size of the asset purchase program was subsequently increased, reaching $£ 375$ billion by the end of 2012, approximately 30 per cent of the stock of outstanding nominal government debt in the United Kingdom. In addition, the maturity buying range was also extended to include gilts with a residual maturity greater than three years in August 2009.

\section{Results}

Overall, we consider eight asset purchase announcements for the BoE's QE program. These dates, and their specific details, are described in Table 3. Our event set is similar to those analyzed in Christensen and Rudebusch (2012) and Joyce et al. (2011), with two differences: First, we include asset purchase announcements in 2011 and 2012 that followed the publication of these papers. Second, we exclude the announcement on February 4, 2010, given that the announcement did not indicate an expansion of the program. Our results remain qualitatively the same if we use the original event sets employed in these two papers.

Table 4 summarizes the results regarding the response of long-term gilts to the BoE's asset purchase announcements. Interestingly, the first two dates in our event study (February 11, 2009, and March 5, 2009) had a significantly larger impact on 10-year yields compared with the subsequent events. The February date marks the publication of the Inflation Report, where the possibility of introducing QE was first raised, whereas the LSAP program was officially launched in March 2009. The yields on 10-year gilts fell 35 bps and 67 bps on these two dates, respectively (see Panel A of Table 4). These two announcements differ, however, in the channel through which they affected the yields.

Following the February 2009 announcement, almost the entire change in the yield is due to a fall in the expectations component ( $29 \mathrm{bps})$. The change in the term premium, on the other hand, is economically small (6 bps) and not significant at the 5 per cent level. Such movement can potentially be explained by the fact that, at the time, the policy rate was still 50 bps above the considered effective lower bound, and no purchases were made, nor any details regarding future purchases announced. As such, the February 2009 Inflation Report was mainly viewed as a signal of the impending rate cut later announced at the March 2009 meeting of the BoE's MPC. 
On the other hand, the term premium fell significantly subsequent to the launch of the BoE's QE program in March 2009. The 56 bps drop in term premia, roughly 80 per cent of the total drop in long-term yields, is mainly due to the fall in the country-specific term premium (41 bps). While the fall of the global component of the term premium is small (15 bps) compared with the overall reduction in 10-year gilt yields, it is still both economically important and statistically significant. It is also the main contributor to the fall in the yields of the rest of the countries that day (see Panel B of Table 4). In fact, we interpret the change in the global term premium component to partly reflect that the March 5, 2009, BoE announcement could have been interpreted by investors as signaling the impending start of the Federal Reserve's purchase of U.S. Treasury bonds (as indeed was the case two weeks later on March 18, 2009).

Similar to the case of the Federal Reserve's QE program and consistent with Haldane et al. (2016), subsequent rounds of asset purchases by the BoE tend to have a much lower impact on yields; in fact, yields even increased around certain announcements. We propose three potential explanations for this result. First, these results are consistent with the view that investors may have partially anticipated some of the BoE's asset purchases. Second, it can be the case that the full effect of the announcement is only partially captured by two-day changes. For example, Greenwood, Hanson and Liao (2016) propose a model where, due to institutional and informational frictions, capital across asset classes moves slowly and therefore the full effect of an asset purchase program can take longer than two days to take full effect. Third, it could be possible that the BoE program was too small to counteract the concurrent monetary expansions embarked on by the Fed through their corresponding asset purchase programs.

Apart from the February 2009 Inflation Report and the March 2009 monetary policy decision, which had an effect on global yields of similar magnitude to the Fed's QE announcements, the BoE's asset purchase announcements did not significantly affect the 10 -year yields in the rest of the world.

\section{Sweden}

We now turn to the response of long-term yields to the Riksbank's asset purchase announcements.

\section{The Riksbank's QE program}

To fight the deflationary pressures building in the Swedish economy in the last few years, the Riksbank announced in February 2015 the purchase of government bonds with maturities of up to five years for the amount of SEK 10 billion. ${ }^{23}$ Simultaneously, the Riksbank cut its repo rate by 10 bps to -0.10 per cent, taking it into negative rate territory for the first time in the

\footnotetext{
${ }^{23}$ In October 2012, previous to the announcement of asset purchases, the Riksbank established a securities portfolio to ensure that the required systems, agreements and knowledge were in place if the need to take extraordinary measures arose.
} 
history of Sweden, and emphasized that, if necessary, it would take further measures, even between the ordinary monetary policy decisions. Indeed, in March 2015, between two regular monetary policy meetings, the Executive Board of the Riksbank decided to cut the repo rate by a further $15 \mathrm{bps}$, to increase purchases of government bonds by SEK 30 billion and to extend the maturity of bonds purchased to beyond five years. Further asset purchases were announced on five other occasions between 2015 and 2016, and the repo rate was eventually lowered to -0.50 per cent. The subsequent purchases were significantly larger than the initial SEK 10 billion (ranging between SEK 45 billion to 200 billion), and reached SEK 245 billion by April 2016, approximately 40 per cent of the stock of outstanding nominal government debt in Sweden. ${ }^{24}$

\section{Results}

Table 5 provides specific details on the Riksbank's six asset purchase announcements.

Our results seem to indicate that changes in the yields were the largest on dates when both an increase in the size of the asset purchase program was announced and the policy rate was cut. This is the case of the initial QE announcement in February 2015, when Swedish yields fell 15 bps, and with the announcements in March 2015 and July 2015, when yields fell 13 bps and 17 bps, respectively (see Panel A of Table 6). Not surprisingly, most of the fall in Swedish yields on these three dates is mainly due to the expectations component of interest rates (13.5, -7, and $-13 \mathrm{bps}$, respectively). The drop of the term premium for the March 2015 announcement is mainly due to a fall in the global component of the term premium (which, although statistically significant, is economically trivial). In the case of the July 2015 announcement, the fall in the term premium is due to the country-specific component. However, the magnitude of the fall (3 bps) is neither economically nor statistically significant.

Given the small number of announcements, it is difficult to differentiate between the effect of the LSAP announcement and that of the rate cut into negative territory. ${ }^{25}$ However, three factors suggest that the QE-specific effects were small in the case of the Riksbank's program: First, the drop in yields around the announcement days when there was no policy rate cut was small, or indeed the yields rose on certain occasions. Second, most of the effect on long-term yields comes from the signaling channel (which should stronger for rate cuts). Third, whenever term premia were affected, the reduction was due to a lowering of the global term premia. $^{26}$

\footnotetext{
${ }^{24}$ Further details of the Riksbank's QE program can be found in De Rezende (2016).

${ }^{25}$ See De Rezende (2016) for an attempt to disentangle these two effects for assessing the effectiveness of the Riksbank's QE program.

${ }^{26}$ Alternatively, it could be that investors may have partially anticipated some further asset purchases or even further rate cuts on these pure QE announcements. For example, it seems that investors had formed expectations of further rate cuts for the April 2015 policy decision, which led to an increase in the Swedish bond yields by 13 bps as market participants repriced their expectations.
} 
Contrary to the experience of the U.S. asset purchase program (and to a lesser extent the U.K. program as well), the effects of the Riksbank asset purchase announcements are almost entirely associated with Swedish yields (see Panel B of Table 6). Only on one occasion (March 2015) did the average 10-year yields in the rest of the world fall following an announcement in Sweden. This observation is consistent with the idea that, as a small open economy, the effect of Sweden's asset purchase programs on other countries' bond yields tends to be negligible. In other words, these results seem to suggest that the central banks of small open economies cannot purchase enough domestic (or foreign) assets to significantly shift the global term premium via domestic quantitative easing.

\section{Switzerland}

In this section, we analyze two of the unconventional monetary policy programs implemented by the SNB: the asset purchase program implemented in 2009 and the reserve expansion program implemented in 2011. It is important to bear in mind that, in contrast to the experiences in the United States, United Kingdom and Sweden, the SNB so far has not bought Swiss government bonds. Still, we believe these programs provide an interesting and different perspective on which channels are at play when one consider unconventional monetary policies in small open economies.

\section{The Swiss National Bank's QE program}

On March 12, 2009, the SNB adopted a number of monetary policy tools aimed at fighting the deflationary pressures building in the Swiss economy as a consequence of the strong appreciation of the Swiss franc due to its status of safe-haven currency. ${ }^{27}$ These unconventional measures included foreign exchange intervention, the extension of the maturity for repo operations, and a (small) bond purchase program targeted at Swiss franc private sector bonds. The measures aimed to improve liquidity conditions as well as lower the upward pressures on the exchange rate.

Although at the time of the announcement no specific information about the intended size or type of bonds was given, it was eventually made public that the SNB purchased covered and corporate bonds. Later, in December 2009, the SNB announced that the bond purchase was complete. Uniquely among the programs we have considered, the SNB subsequently sold the purchased bonds, discretely, between March and August 2010. At the height of the program, bond purchases totaled CHF 3 billion: a small program when compared with the size of the one undertaken by the Federal Reserve.

\footnotetext{
${ }^{27}$ Further details of the SNB's QE program can be found in Mirkov and Sutter (2011) and Kettemann and Krogstrup (2014), for example.
} 


\section{Expansion of reserves}

Against the backdrop of the market turmoil caused by the European debt crisis of 2011, which led to a rapid appreciation of the Swiss franc and increased deflationary concerns for the Swiss economy, the SNB announced on August 3, 2011, that it would lower the top of the operating band for the Swiss franc LIBOR from 75 to $25 \mathrm{bps}$ and would expand reserves held at the SNB. ${ }^{28}$ In this case, the SNB expanded its balance sheet through purchases of shortterm debt securities, repo operations and short-term foreign exchange swaps (rather than through the purchase of long-term Swiss franc bonds, whose market supply remained constant). The objective of this policy was to put downward pressure on money market interest rates and thus counter the Swiss franc overvaluation.

As the exchange rate continued to appreciate after this announcement, the SNB announced two additional reserve expansions on August 10 and August 17 and also used foreign exchange swaps to implement the reserve expansion. In sum, reserves were expanded from CHF 30 billion to 200 billion - an increase equivalent to approximately 30 per cent of Swiss GDP in 2011.

In fact, Bernanke and Reinhart (2004) and, more recently, Christensen and Krogstrup (2016a) have pointed out that alternative portfolio balance effects also arise due to the increase in the supply of central bank reserves that accompanies a typical LSAP program. In this sense, an increase in the supply of central bank reserves can put upward pressure on bond prices in particular and asset prices in general, even if the supply of long-term bonds remains intact, due to a special characteristic of reserves: they can be held only by banks. In contrast to the traditional supply-induced portfolio balance effect described above, Christensen and Krogstrup (2016a) refer to this new channel as a reserve-induced portfolio balance channel. ${ }^{29}$

\section{Results}

Table 7 shows the details of the four dates that we focus on in this paper (the announcement of the Swiss QE program in 2009 and the SNB's three reserve expansion announcements in 2011).

Our results suggest that the SNB asset purchase program announcement in March 2009 had a very limited effect. In this case, Swiss bond yields fell by 5 bps (see Panel A of Table 8). Specifically, most of the drop in yields was due to the expectations component, which fell around $10 \mathrm{bps}$, which implies a 5 bps increase in the term premium component (mainly due to the increase in the country-specific component of the term premia). This contrasts with the

\footnotetext{
${ }^{28}$ Further details of the SNB reserve expansion program can be found in Christensen and Krogstrup (2016a), among others.

${ }^{29}$ See Christensen and Krogstrup (2016b) for a formal model of the reserve-induced portfolio balance channel.
} 
results in Kettemann and Krogstrup (2014), which suggest that the SNB's bond purchase program had an effect on the yields of the purchased (private sector) bonds.

While the Swiss QE program did not include the purchase of government bonds, we would have expected spillover effects from private sector bonds and thus a reduction in the yields of Swiss government bonds (as they are, in principle, close substitutes). Thus, we should have seen the term premium component of Swiss government bonds falling as well (as happened in the United States when the Fed bought agency bonds). We attribute this slightly puzzling result to the lack of specific information about the intended size and type of bonds, thus potentially leading to increased uncertainty in the market. Moreover, we find no evidence of international spillover effects, neither signaling nor portfolio balance (see Panel B of Table 8).

As for the reserve expansion program, the only significant reduction in yields occurs around the third reserve expansion announcement, on August 17, 2011, where yields drop by 20 basis points. The majority - close to 70 per cent — of this reduction in yields is due to lower term premia. This result is consistent with those of Christensen and Krogstrup (2016a), who also study the SNB's reserve expansion program. However, our results differ slightly from theirs in that our model gives more weight to the signaling channel (yet, in practice, our results are qualitatively similar in that, with the exception of the August 17 announcement, the change is not statistically significant). We believe that the difference in results is not completely surprising, given that Christensen and Krogstrup (2016a) do not deal directly with the persistence problem inherent in interest rates and therefore are likely to overestimate the importance of the portfolio balance channel (see, e.g., the discussions in Christensen and Rudebusch, 2012, and Bauer and Rudebusch, 2014).

More importantly, our model seems to attribute 60 per cent of the drop in the term premium component to global factors. Under the assumption that a small open economy is unlikely to affect the global component of the term premium, the contribution of the reserve-induced portfolio balance channel to the fall on bond yields on August 17 was only 6 bps (i.e., the fall in the country-specific term premium component). Although this is statistically significant, it is much lower than the 20 bps contribution found by Christensen and Krogstrup (2016a). Along these lines, it is important to point out that on August 18, 2011, there was a major selloff in European bank stocks and an increase in market volatility due to market rumours that the ECB dollar facility was tapped for the first time since early 2011 (see Appendix H in Christensen and Krogstrup, 2016a, for a list of important events in August and September 2011). This sell-off in European stocks likely led international investors to purchase government bonds around the world (a flight-to-quality event) thus pushing their yields down. Unlike previous papers in the literature, our decomposition of the term premium into a global and a country-specific component allows us to control for the effects of these global events when analyzing the impact of asset purchases in small open economies. 


\section{FinAL REMARKS}

We have examined the effects of asset purchase programs undertaken by the Federal Reserve, the BoE, the Riksbank and the SNB and their ability to reduce long-term government bond yields. To this end, we have decomposed government bond yields in these countries into three components: (i) the expectations component, (ii) a global term premium and (iii) a countryspecific term premium component. We have used this decomposition in an event study to analyze two-day changes on 10-year yields around announcement days to shed light on the effectiveness of these asset purchase programs.

Our analysis suggests that, in general, the changes in long-term rates around asset purchase announcements by the BoE, the Riksbank and the SNB are smaller than the changes observed after the first round of asset purchases implemented by the Federal Reserve. Furthermore, our results suggest that, unlike the U.S. LSAP announcements, and to some extent those in the United Kingdom, the QE programs in Sweden and Switzerland do not affect the global term premium component of the yields. Our explanation for this observation is the relatively small size of the asset purchase programs in small open economies when compared with the size of the pool of substitutable assets, which includes foreign bonds. Consequently, we argue, the effectiveness of these programs in reducing long-term interest rates has been limited.

One open question is whether the limits to the effectiveness of asset purchases in lowering long-term interest rates in small open economies would force most of the portfolio balance adjustment through the exchange rate channel, or whether the exchange rate adjustment would be limited as well. For example, Glick and Leduc $(2012,2015)$ and Neely (2015) find that the U.S. dollar tended to depreciate around the Federal Reserve's asset purchase announcements. We leave this issue for further research. 
Figures and Tables

Figure 1. Estimated Factors

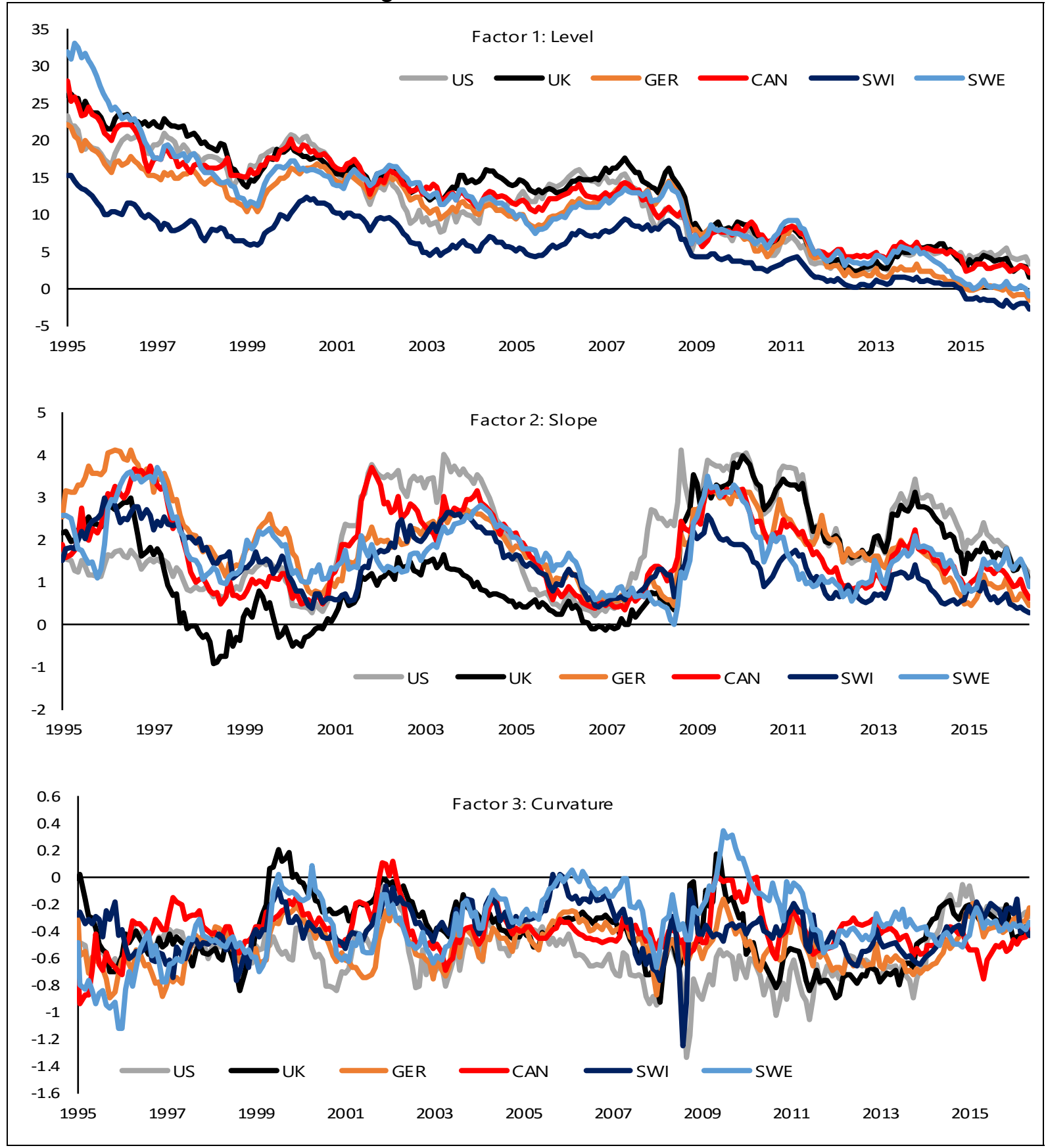


Figure 2. Factor Loadings on Principal Components

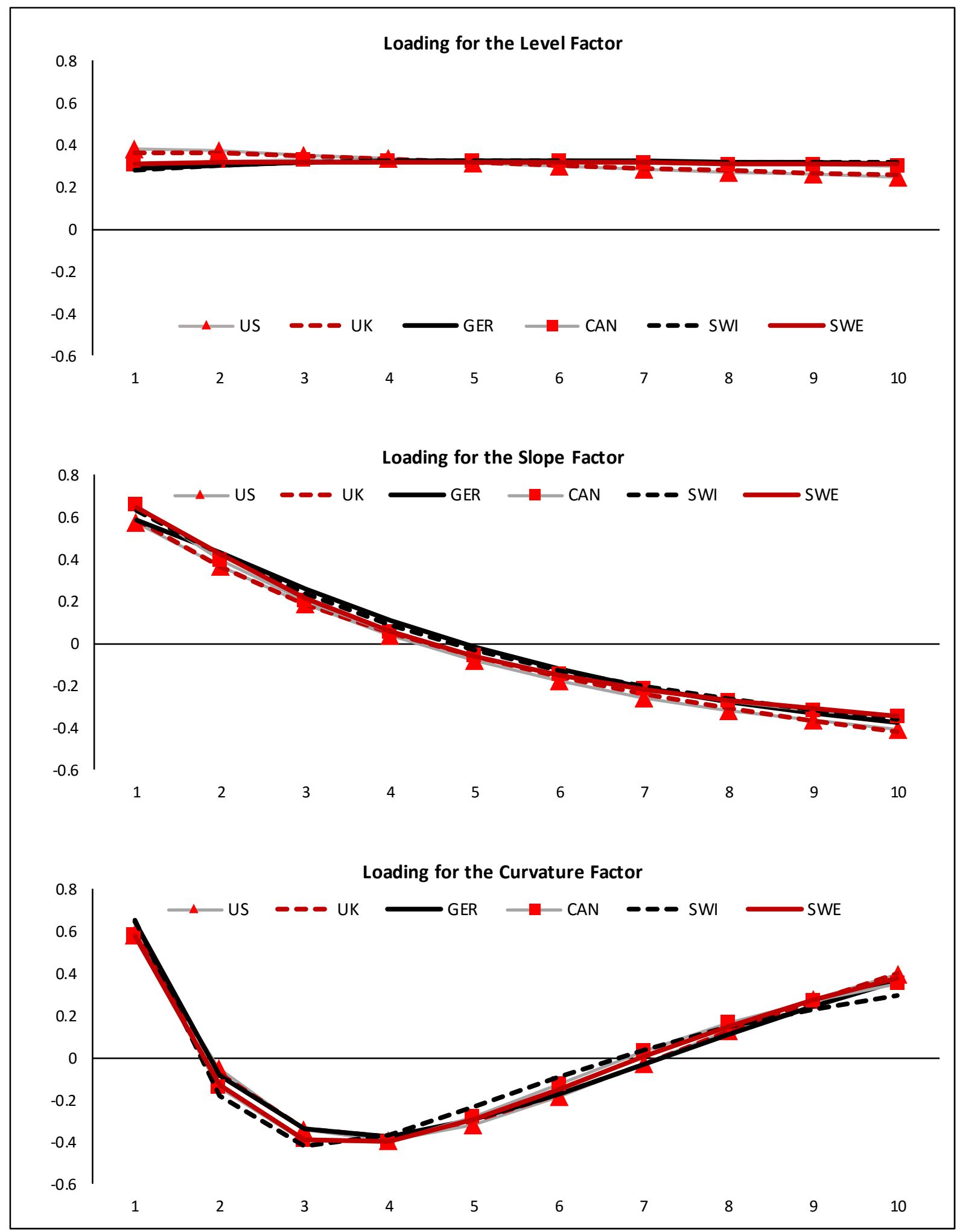


Figure 3. Yield Decomposition by Country
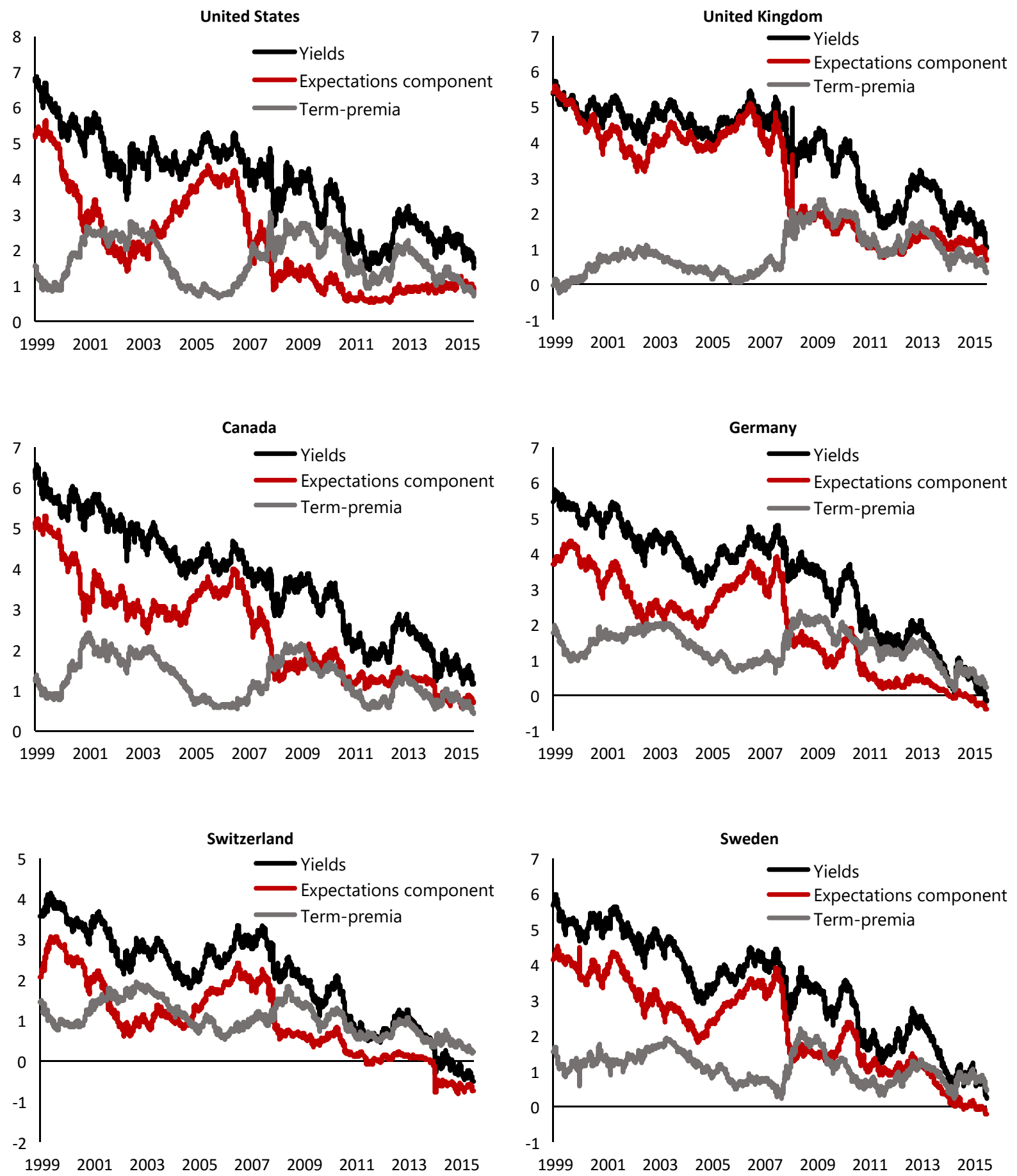
Figure 4. Global Component of Countries' Term Premia

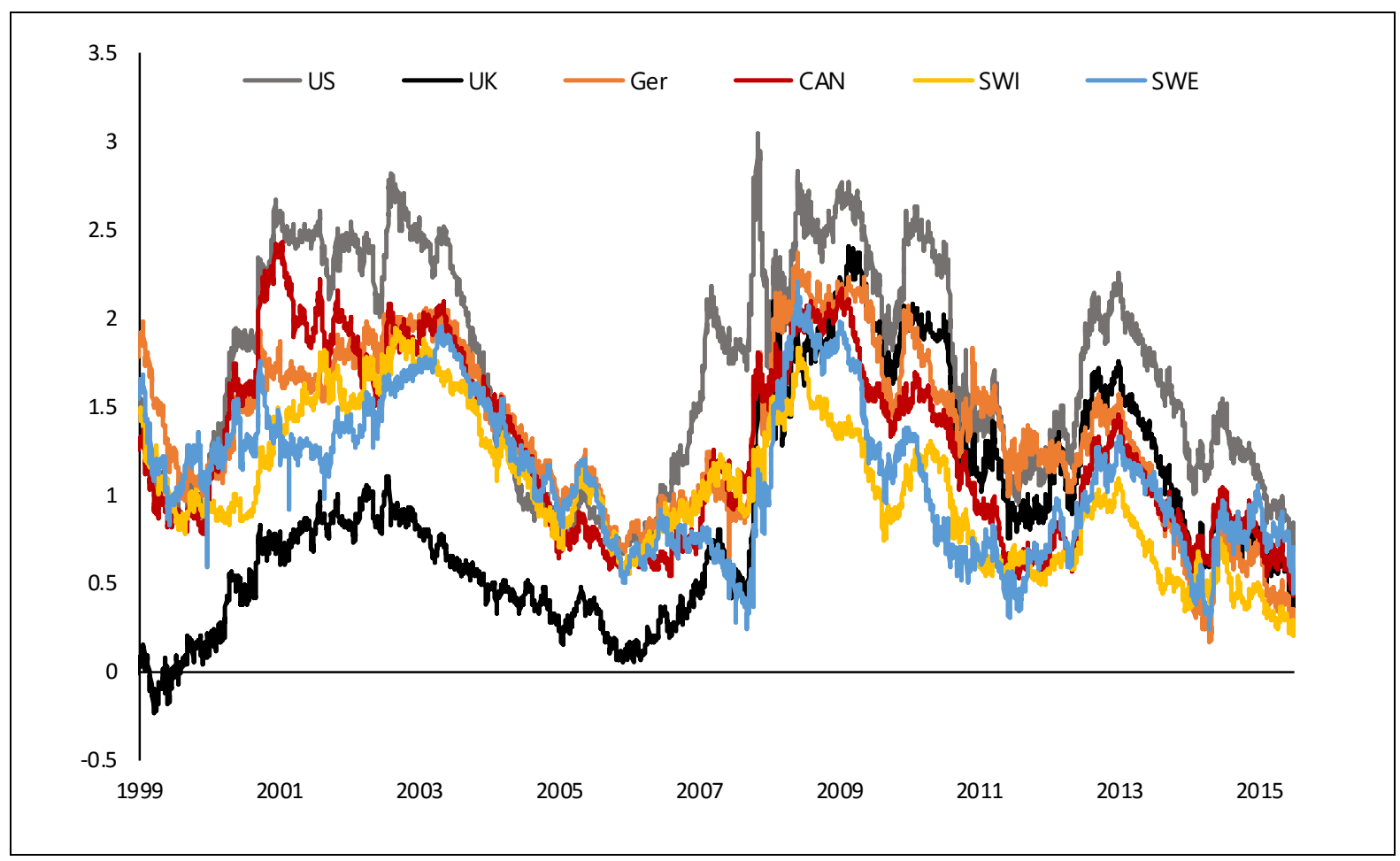


Figure 5. Movements in Yields and Premia

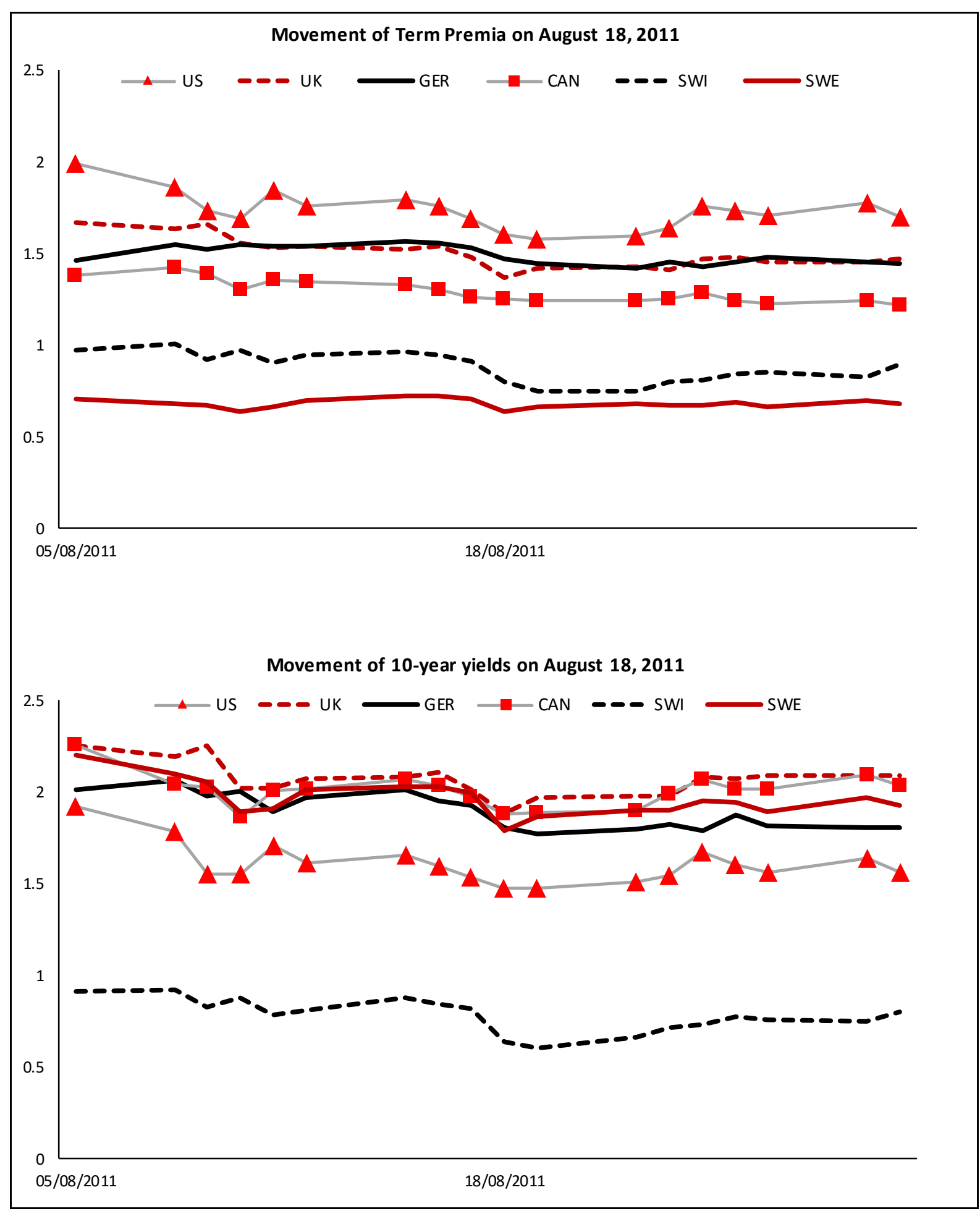


Table 1. Federal Reserve's Asset Purchase Announcements

\begin{tabular}{|c|c|c|c|}
\hline Date & Program & Event & Description \\
\hline 25-Nov-08 & QE1 & $\begin{array}{l}\text { Initial LSAP } \\
\text { announcement }\end{array}$ & $\begin{array}{l}\text { The Federal Reserve announces purchases of up to } \$ 100 \text { billion in } \\
\text { agency debt and up to } \$ 500 \text { billion in agency mortgage-backed } \\
\text { securities (MBS). }\end{array}$ \\
\hline 1-Dec-08 & QE1 & Bernanke's speech & $\begin{array}{l}\text { Chairman Bernanke mentions that the Fed could purchase long- } \\
\text { term Treasuries. }\end{array}$ \\
\hline 16-Dec-08 & QE1 & $\begin{array}{l}\text { Federal Open } \\
\text { Market Committee } \\
\text { (FOMC) statement }\end{array}$ & $\begin{array}{l}\text { Statement indicates that the FOMC is considering expanding } \\
\text { purchases of agency securities and initiating purchases of Treasury } \\
\text { securities. Also, the fed funds rate target was reduced from } 1 \% \text { to a } \\
0-25 \text { bps target rate. }\end{array}$ \\
\hline 28-Jan-09 & QE1 & FOMC statement & $\begin{array}{l}\text { The FOMC indicates it is considering expanding purchases of } \\
\text { agency debt and initiating purchases of Treasuries. }\end{array}$ \\
\hline 18-Mar-09 & QE1 & FOMC statement & $\begin{array}{l}\text { Statement announces purchases "up to an additional } \$ 750 \text { billion } \\
\text { of agency [MBS]," } \$ 100 \text { billion in agency debt, and } \$ 300 \text { billion in } \\
\text { Treasury securities. }\end{array}$ \\
\hline 10-Aug-10 & QE2 & FOMC statement & $\begin{array}{l}\text { Balance sheet maintained: The Fed will reinvest principal payments } \\
\text { from LSAP purchases in Treasuries. }\end{array}$ \\
\hline 27-Aug-10 & QE2 & Bernanke's speech & $\begin{array}{l}\text { Chairman states that the FOMC "is prepared to provide additional } \\
\text { monetary accommodation through unconventional measures." }\end{array}$ \\
\hline 21-Sep-10 & QE2 & FOMC statement & $\begin{array}{l}\text { Statement projects that inflation "is likely to remain subdued for } \\
\text { some time before rising to levels the Committee considers } \\
\text { consistent with its mandate." }\end{array}$ \\
\hline $15-O c t-10$ & QE2 & Bernanke's speech & $\begin{array}{l}\text { Chairman Bernanke states that "given the Committee's objectives, } \\
\text { there would appear-all else being equal-to be a case for further } \\
\text { action." }\end{array}$ \\
\hline 3-Nov-10 & QE2 & FOMC statement & $\begin{array}{l}\text { Statement announces purchases of } \$ 600 \text { billion in Treasury } \\
\text { securities. }\end{array}$ \\
\hline 22-Aug-12 & QE3 & FOMC minutes & $\begin{array}{l}\text { FOMC members "judged that additional monetary accommodation } \\
\text { would likely be warranted fairly soon." }\end{array}$ \\
\hline 31-Aug-12 & QE3 & Bernanke's speech & $\begin{array}{l}\text { Chairman Bernanke states that the Fed "...will provide additional } \\
\text { policy accommodation as needed"--which the market interprets as } \\
\text { increasing the odds of further QE. }\end{array}$ \\
\hline 13-Sep-12 & QE3 & FOMC statement & $\begin{array}{l}\text { The Fed will purchase } \$ 40 \text { billion of MBS per month as long as "the } \\
\text { outlook for the market does not improve substantially [...] in the } \\
\text { context of price stability." }\end{array}$ \\
\hline 12-Dec-12 & QE3 & FOMC statement & $\begin{array}{l}\text { The Fed announces it will purchase longer-term Treasury securities } \\
\text { after the Maturity Extension Program is completed at the end of } \\
\text { the year, initially at a pace of } \$ 45 \text { billion per month, and will } \\
\text { continue purchases of } \$ 40 \text { billion of agency MBS per month. }\end{array}$ \\
\hline
\end{tabular}


Table 2. Changes on Bond Yields on Fed Asset Purchase Announcement Days

\begin{tabular}{|c|c|c|c|c|c|c|}
\hline Program & Date & 10y Yield & Expectations & Term Premium & $\begin{array}{l}\text { Global Term } \\
\text { Premium }\end{array}$ & $\begin{array}{l}\text { Country-Specific } \\
\text { Term Premium }\end{array}$ \\
\hline \multicolumn{7}{|c|}{ Panel A: US } \\
\hline \multirow{12}{*}{ US-QE1 } & 25-Nov-08 & $-31.3^{* *}$ & $-16.5^{* *}$ & $-14.8^{* *}$ & $-8.5^{* *}$ & $-6.3^{*}$ \\
\hline & & $(0.00)$ & $(0.01)$ & $(0.01)$ & $(0.00)$ & $(0.04)$ \\
\hline & 1-Dec-08 & $-25.3^{* *}$ & $-12.4^{*}$ & $-12.9^{*}$ & -2.3 & $-10.6^{* *}$ \\
\hline & & $(0.00)$ & $(0.02)$ & $(0.01)$ & (0.11) & $(0.01)$ \\
\hline & 16-Dec-08 & $-38.6^{* *}$ & -6.9 & $-31.7 * * *$ & $-6.6 * *$ & $-25.1 * * *$ \\
\hline & & $(0.00)$ & $(0.10)$ & $(0.00)$ & $(0.00)$ & $(0.00)$ \\
\hline & 28-Jan-09 & 27.1 & 12.8 & 14.4 & 2.6 & 11.7 \\
\hline & & $(1.00)$ & (0.98) & (0.99) & (0.91) & $(1.00)$ \\
\hline & 18-Mar-09 & $-51.2 * * *$ & $-21.4^{* *}$ & $-29.8^{* * *}$ & $-7.7 * *$ & $-22.1^{* *}$ \\
\hline & & $(0.00)$ & $(0.00)$ & $(0.00)$ & $(0.00)$ & $(0.00)$ \\
\hline & Average & $-23.9 * *$ & -8.9 & $-15^{* *}$ & $-4.5^{*}$ & $-10.5^{* *}$ \\
\hline & & $(0.01)$ & $(0.05)$ & $(0.01)$ & $(0.02)$ & $(0.01)$ \\
\hline \multirow{12}{*}{ US-QE2 } & 10-Aug-10 & $-14.9 *$ & -4.6 & $-10.3^{*}$ & -1.7 & $-8.6^{*}$ \\
\hline & & (0.03) & $(0.17)$ & $(0.02)$ & (0.18) & $(0.01)$ \\
\hline & 27-Aug-10 & 4.4 & 0.4 & 4 & 0 & 4 \\
\hline & & $(0.75)$ & $(0.56)$ & $(0.84)$ & $(0.55)$ & (0.89) \\
\hline & 21-Sep-10 & $-16.8^{*}$ & -5.1 & $-11.7^{*}$ & $-4.9 *$ & $-6.8 *$ \\
\hline & & $(0.02)$ & $(0.15)$ & $(0.01)$ & $(0.01)$ & $(0.03)$ \\
\hline & $15-$ Oct-10 & 0.8 & -1.6 & 2.4 & 2.7 & -0.3 \\
\hline & & (0.58) & $(0.36)$ & $(0.75)$ & (0.91) & (0.46) \\
\hline & 3-Nov-10 & -12.4 & -5.1 & $-7.3^{*}$ & -1.3 & $-6^{*}$ \\
\hline & & $(0.06)$ & $(0.15)$ & $(0.05)$ & $(0.25)$ & $(0.04)$ \\
\hline & Average & -7.8 & -3.2 & -4.6 & -1 & -3.5 \\
\hline & & $(0.16)$ & $(0.25)$ & (0.13) & $(0.29)$ & $(0.12)$ \\
\hline \multirow{9}{*}{ US-QE3 } & 22-Aug-12 & $-14.1^{*}$ & -4.8 & $-9.2^{*}$ & $-5.5^{* *}$ & -3.8 \\
\hline & & (0.04) & (0.16) & $(0.03)$ & $(0.01)$ & (0.11) \\
\hline & 31-Aug-12 & -7 & -3.5 & -3.5 & 0.3 & -3.8 \\
\hline & & (0.18) & $(0.23)$ & (0.19) & $(0.60)$ & (0.11) \\
\hline & 13-Sep-12 & 11.5 & 1.9 & 9.6 & 3.5 & 6.1 \\
\hline & & (0.92) & $(0.70)$ & (0.97) & (0.95) & (0.96) \\
\hline & 12-Dec-12 & 8.9 & 2.3 & 6.5 & 1.6 & 5 \\
\hline & & $(0.87)$ & $(0.73)$ & $(0.92)$ & $(0.82)$ & (0.93) \\
\hline & Average & -0.2 & -1 & 0.9 & 0 & 0.9 \\
\hline
\end{tabular}


Table 2. Changes on Bond Yields on Fed Asset Purchase Announcement Days (continued)

\begin{tabular}{|c|c|c|c|c|c|c|}
\hline Program & Date & 10y Yield & Expectations & Term Premium & $\begin{array}{c}\text { Global Term } \\
\text { Premium }\end{array}$ & $\begin{array}{l}\text { Country-Specific } \\
\text { Term Premium }\end{array}$ \\
\hline \multicolumn{7}{|c|}{ Panel B: Average Ex-US } \\
\hline \multirow{12}{*}{ US-QE1 } & 25-Nov-08 & $-10.8^{*}$ & 0.1 & $-10.9 * *$ & $-11.6^{* *}$ & 0.7 \\
\hline & & $(0.02)$ & $(0.55)$ & $(0.00)$ & $(0.00)$ & (0.91) \\
\hline & 1-Dec-08 & $-15.4^{* *}$ & $-14.1^{* *}$ & -1.3 & -3.2 & 1.9 \\
\hline & & $(0.00)$ & $(0.00)$ & $(0.30)$ & (0.11) & $(1.00)$ \\
\hline & 16-Dec-08 & $-19.8^{* *}$ & $-14.7^{* *}$ & $-5.2^{*}$ & $-9 * *$ & 3.9 \\
\hline & & $(0.00)$ & $(0.00)$ & $(0.02)$ & $(0.00)$ & $(1.00)$ \\
\hline & 28-Jan-09 & 0.4 & -1.2 & 1.7 & 3.6 & $-1.9 * *$ \\
\hline & & (0.58) & $(0.34)$ & $(0.78)$ & (0.91) & $(0.00)$ \\
\hline & 18-Mar-09 & $-10.4^{*}$ & -3.2 & $-7.2^{* *}$ & $-10.5^{* *}$ & 3.3 \\
\hline & & $(0.02)$ & $(0.15)$ & $(0.01)$ & $(0.00)$ & $(1.00)$ \\
\hline & Average & $-11.2^{*}$ & $-6.6^{*}$ & $-4.6^{*}$ & $-6.1^{*}$ & 1.6 \\
\hline & & $(0.01)$ & $(0.03)$ & $(0.04)$ & $(0.02)$ & $(0.99)$ \\
\hline \multirow{12}{*}{ US-QE2 } & 10-Aug-10 & -7.2 & $-5.9 *$ & -1.3 & -2.4 & 1.1 \\
\hline & & (0.06) & $(0.04)$ & $(0.30)$ & (0.18) & $(0.97)$ \\
\hline & 27-Aug-10 & 0.7 & 1 & -0.3 & 0.1 & -0.4 \\
\hline & & $(0.60)$ & (0.68) & $(0.47)$ & $(0.55)$ & $(0.20)$ \\
\hline & 21-Sep-10 & $-11.4^{*}$ & $-5.6^{*}$ & $-5.8^{*}$ & $-6.7^{*}$ & 0.9 \\
\hline & & (0.01) & $(0.05)$ & $(0.02)$ & $(0.01)$ & $(0.95)$ \\
\hline & $15-O c t-10$ & 6.3 & 2.4 & 3.9 & 3.7 & 0.2 \\
\hline & & (0.91) & $(0.82)$ & (0.93) & (0.91) & $(0.67)$ \\
\hline & 3-Nov-10 & -2.2 & -1.2 & -0.9 & -1.8 & 0.8 \\
\hline & & $(0.35)$ & (0.34) & (0.36) & $(0.25)$ & (0.94) \\
\hline & Average & -2.8 & -1.9 & -0.9 & -1.4 & 0.5 \\
\hline & & $(0.30)$ & $(0.27)$ & $(0.36)$ & $(0.29)$ & $(0.87)$ \\
\hline \multirow{10}{*}{ US-QE3 } & 22-Aug-12 & $-10.9 *$ & -4.3 & $-6.6^{*}$ & $-7.4^{* *}$ & 0.8 \\
\hline & & $(0.02)$ & $(0.09)$ & $(0.01)$ & $(0.01)$ & (0.94) \\
\hline & 31-Aug-12 & 0.9 & -0.1 & 1 & 0.4 & 0.6 \\
\hline & & $(0.61)$ & (0.51) & $(0.69)$ & $(0.60)$ & $(0.90)$ \\
\hline & $13-S e p-12$ & 5.6 & 1.7 & 3.9 & 4.8 & -0.9 \\
\hline & & $(0.89)$ & $(0.75)$ & (0.93) & (0.95) & $(0.05)$ \\
\hline & 12-Dec-12 & 3.6 & 2.1 & 1.5 & 2.1 & -0.6 \\
\hline & & $(0.80)$ & $(0.80)$ & $(0.76)$ & $(0.82)$ & (0.11) \\
\hline & Average & -0.2 & -0.2 & -0.1 & 0 & 0 \\
\hline & & $(0.52)$ & $(0.51)$ & $(0.52)$ & $(0.53)$ & $(0.46)$ \\
\hline
\end{tabular}

Note: $\left({ }^{* *}\right),\left({ }^{* *}\right)$, and $\left({ }^{*}\right)$ indicate coefficient significantly different from zero at the $1 \%, 5 \%$ and $10 \%$ level, respectively. Average Ex-US indicates the average change on bond yields across the countries in our study with the exception of the U.S. 


\section{Table 3. Bank of England Asset Purchase Announcements}

\begin{tabular}{|c|c|c|c|}
\hline Date & Program & Event & Description \\
\hline 11-Feb-09 & UK-QE & $\begin{array}{l}\text { February Inflation } \\
\text { Report }\end{array}$ & $\begin{array}{l}\text { Press conference and Inflation Report indicated that asset } \\
\text { purchases were likely. }\end{array}$ \\
\hline 5-Mar-09 & UK-QE & MPC Statement & $\begin{array}{l}\text { The MPC announced that it would purchase } f 75 \text { billion of assets } \\
\text { over three months financed by central bank reserves. Gilt } \\
\text { purchases were to be restricted to bonds with a residual maturity } \\
\text { of between } 5 \text { and } 25 \text { years. Also, the policy rate was cut from } 1 \% \\
\text { to } 0.50 \% \text {. }\end{array}$ \\
\hline 7-May-09 & UK-QE & MPC Statement & $\begin{array}{l}\text { The MPC announced that the amount of QE asset purchases would } \\
\text { be extended to } f 125 \text { billion. }\end{array}$ \\
\hline 6-Aug-09 & UK-QE & MPC Statement & $\begin{array}{l}\text { The MPC announced that the amount of QE asset purchases would } \\
\text { be extended to } f 175 \text { billion and that the buying range would be } \\
\text { extended to gilts with a residual maturity greater than three years. }\end{array}$ \\
\hline 5-Nov-09 & UK-QE & MPC Statement & $\begin{array}{l}\text { The MPC announced that the amount of QE asset purchases would } \\
\text { be extended to } f 200 \text { billion. }\end{array}$ \\
\hline 6-Oct-11 & UK-QE & MPC Statement & $\begin{array}{l}\text { The MPC announced that the amount of QE asset purchases would } \\
\text { be extended to } f 275 \text { billion. }\end{array}$ \\
\hline 9-Feb-12 & UK-QE & MPC Statement & $\begin{array}{l}\text { The MPC announced that the amount of QE asset purchases would } \\
\text { be extended to } f 325 \text { billion. }\end{array}$ \\
\hline 5-Jul-12 & UK-QE & MPC Statement & $\begin{array}{l}\text { The MPC announced that the amount of QE asset purchases would } \\
\text { be extended to } f 375 \text { billion. }\end{array}$ \\
\hline
\end{tabular}




\section{Table 4. Changes on Bond Yields on Bank of England Asset Purchase Announcement Days}

\begin{tabular}{|c|c|c|c|c|c|c|}
\hline Program & Date & 10y Yield & Expectations & Term Premium & $\begin{array}{c}\text { Global Term } \\
\text { Premium } \\
\end{array}$ & $\begin{array}{c}\text { Country-Specific } \\
\text { Term Premium }\end{array}$ \\
\hline \multicolumn{7}{|c|}{ Panel A: UK } \\
\hline \multirow{9}{*}{ UK-QE } & 11-Feb-09 & $\begin{array}{l}-35 * * \\
(0.00)\end{array}$ & $\begin{array}{c}-29.2 * * * \\
(0.00)\end{array}$ & $\begin{array}{l}-5.8 \\
(0.06)\end{array}$ & $\begin{array}{l}-5.6^{*} \\
(0.02)\end{array}$ & $\begin{array}{l}-0.2 \\
(0.46)\end{array}$ \\
\hline & 5-Mar-09 & $\begin{array}{c}-67 * * * \\
(0.00)\end{array}$ & $\begin{array}{l}-11.1^{*} \\
(0.01)\end{array}$ & $\begin{array}{c}-55.9 * * * \\
(0.00)\end{array}$ & $\begin{array}{c}-14.9 * * * \\
(0.00)\end{array}$ & $\begin{array}{c}-41 * * * \\
(0.00)\end{array}$ \\
\hline & 7-May-09 & $\begin{array}{c}10 \\
(0.93)\end{array}$ & $\begin{array}{c}4.5 \\
(0.89)\end{array}$ & $\begin{array}{c}5.5 \\
(0.92)\end{array}$ & $\begin{array}{c}8.4 \\
(0.99)\end{array}$ & $\begin{array}{l}-2.9 \\
(0.10)\end{array}$ \\
\hline & 6-Aug-09 & $\begin{array}{c}-3 \\
(0.31)\end{array}$ & $\begin{array}{l}-1.2 \\
(0.39)\end{array}$ & $\begin{array}{l}-1.8 \\
(0.30)\end{array}$ & $\begin{array}{c}0.9 \\
(0.69)\end{array}$ & $\begin{array}{l}-2.7 \\
(0.12)\end{array}$ \\
\hline & 5-Nov-09 & $\begin{array}{c}10 \\
(0.93)\end{array}$ & $\begin{array}{l}-0.2 \\
(0.50)\end{array}$ & $\begin{array}{l}10.2 \\
(0.99)\end{array}$ & $\begin{array}{c}3 \\
(0.89)\end{array}$ & $\begin{array}{c}7.2 \\
(0.99)\end{array}$ \\
\hline & $6-$ Oct-11 & $\begin{array}{c}12 \\
(0.95)\end{array}$ & $\begin{array}{c}4.1 \\
(0.86)\end{array}$ & $\begin{array}{c}7.9 \\
(0.97)\end{array}$ & $\begin{array}{c}6.3 \\
(0.98)\end{array}$ & $\begin{array}{c}1.6 \\
(0.76)\end{array}$ \\
\hline & 9-Feb-12 & $\begin{array}{c}-5 \\
(0.22)\end{array}$ & $\begin{array}{l}-4.4 \\
(0.14)\end{array}$ & $\begin{array}{r}-0.6 \\
(0.44)\end{array}$ & $\begin{array}{l}-0.8 \\
(0.37)\end{array}$ & $\begin{array}{c}0.3 \\
(0.56)\end{array}$ \\
\hline & 5-Jul-12 & $\begin{array}{l}-11^{*} \\
(0.05)\end{array}$ & $\begin{array}{l}-7.2 \\
(0.05)\end{array}$ & $\begin{array}{l}-3.8 \\
(0.14)\end{array}$ & $\begin{array}{l}-3.8 \\
(0.06)\end{array}$ & $\begin{array}{c}0 \\
(0.50)\end{array}$ \\
\hline & Average & $\begin{array}{l}-11.1^{*} \\
(0.04) \\
\end{array}$ & $\begin{array}{r}-5.6 \\
(0.10) \\
\end{array}$ & $\begin{array}{r}-5.5 \\
(0.06) \\
\end{array}$ & $\begin{array}{r}-0.8 \\
(0.38) \\
\end{array}$ & $\begin{array}{l}-4.7^{*} \\
(0.03) \\
\end{array}$ \\
\hline \multicolumn{7}{|c|}{ Panel B: Average Ex-UK } \\
\hline \multirow{9}{*}{ UK-QE } & 11-Feb-09 & $\begin{array}{c}-12.9 * * \\
(0.01)\end{array}$ & $\begin{array}{c}-7^{*} \\
(0.03)\end{array}$ & $\begin{array}{l}-5.9 * \\
(0.02)\end{array}$ & $\begin{array}{l}-5.8^{*} \\
(0.02)\end{array}$ & $\begin{array}{c}-0.1 \\
(0.45)\end{array}$ \\
\hline & 5-Mar-09 & $\begin{array}{c}-12.9^{* *} \\
(0.01)\end{array}$ & $\begin{array}{l}-4.7 \\
(0.08)\end{array}$ & $\begin{array}{l}-8.2^{* *} \\
(0.00)\end{array}$ & $\begin{array}{l}-15.5^{* * *} \\
(0.00)\end{array}$ & $\begin{array}{c}7.3 \\
(1.00)\end{array}$ \\
\hline & 7-May-09 & $\begin{array}{r}13.7 \\
(0.99)\end{array}$ & $\begin{array}{c}4.2 \\
(0.92)\end{array}$ & $\begin{array}{c}9.5 \\
(1.00)\end{array}$ & $\begin{array}{c}8.7 \\
(0.99)\end{array}$ & $\begin{array}{c}0.7 \\
(0.94)\end{array}$ \\
\hline & 6-Aug-09 & $\begin{array}{c}4.3 \\
(0.83)\end{array}$ & $\begin{array}{c}2.8 \\
(0.84)\end{array}$ & $\begin{array}{c}1.5 \\
(0.76)\end{array}$ & $\begin{array}{c}0.9 \\
(0.69)\end{array}$ & $\begin{array}{c}0.5 \\
(0.88)\end{array}$ \\
\hline & 5-Nov-09 & $\begin{array}{c}1.2 \\
(0.64)\end{array}$ & $\begin{array}{c}-0.4 \\
(0.48)\end{array}$ & $\begin{array}{c}1.6 \\
(0.76)\end{array}$ & $\begin{array}{c}3.1 \\
(0.89)\end{array}$ & $\begin{array}{l}-1.5^{*} \\
(0.01)\end{array}$ \\
\hline & 6-Oct-11 & $\begin{array}{c}13.2 \\
(0.99)\end{array}$ & $\begin{array}{c}6.4 \\
(0.97)\end{array}$ & $\begin{array}{c}6.8 \\
(0.98)\end{array}$ & $\begin{array}{c}6.6 \\
(0.98)\end{array}$ & $\begin{array}{c}0.2 \\
(0.67)\end{array}$ \\
\hline & 9-Feb-12 & $\begin{array}{c}-1.5 \\
(0.41)\end{array}$ & $\begin{array}{c}-0.5 \\
(0.46)\end{array}$ & $\begin{array}{c}-1 \\
(0.36)\end{array}$ & $\begin{array}{c}-0.9 \\
(0.37)\end{array}$ & $\begin{array}{c}-0.1 \\
(0.38)\end{array}$ \\
\hline & 5-Jul-12 & $\begin{array}{l}-9.5^{*} \\
(0.03)\end{array}$ & $\begin{array}{r}-5.3 \\
(0.06)\end{array}$ & $\begin{array}{l}-4.2 * \\
(0.05)\end{array}$ & $\begin{array}{c}-3.9 \\
(0.06)\end{array}$ & $\begin{array}{c}-0.3 \\
(0.26)\end{array}$ \\
\hline & Average & $\begin{array}{c}-0.6 \\
(0.50)\end{array}$ & $\begin{array}{c}-0.6 \\
(0.45) \\
\end{array}$ & $\begin{array}{c}0 \\
(0.54) \\
\end{array}$ & $\begin{array}{c}-0.8 \\
(0.38) \\
\end{array}$ & $\begin{array}{r}0.8 \\
(0.95) \\
\end{array}$ \\
\hline
\end{tabular}

Note: $\left({ }^{* *}\right),\left({ }^{* *}\right)$, and $(*)$ indicate coefficient significantly different from zero at the $1 \%, 5 \%$ and $10 \%$ level, respectively. Average Ex-UK indicates the average change on bond yields across the countries in our study with the exception of the U.K. 


\section{Table 5. Swedish Riksbank Asset Purchase Announcements}

\begin{tabular}{|c|c|c|c|}
\hline Date & Program & Event & Description \\
\hline $12-F e b-15$ & SWE-QE & Repo rate decision & $\begin{array}{l}\text { The Executive Board announced it would cut the repo rate from } 0 \% \\
\text { to }-0.10 \% \text { and that the Riksbank would buy government bonds for } \\
\text { the sum of SEK } 10 \text { billion. }\end{array}$ \\
\hline 18-Mar-15 & SWE-QE & Repo rate decision & $\begin{array}{l}\text { The Executive Board decided to cut the repo rate by } 15 \text { bps to } \\
-0.25 \% \text { and to buy government bonds for SEK } 30 \text { billion. }\end{array}$ \\
\hline 29-Apr-15 & SWE-QE & Repo rate decision & $\begin{array}{l}\text { The Executive Board decided to extend the purchase of nominal } \\
\text { government bonds by a further SEK } 40-50 \text { billion to a total of SEK } \\
80-90 \text { billion. }\end{array}$ \\
\hline 2-Jul-15 & SWE-QE & Repo rate decision & $\begin{array}{l}\text { The Executive Board decided to cut the repo rate by } 10 \text { bps to } \\
-0.35 \% \text { and to extend the purchase of government bonds to a total } \\
\text { of SEK } 125-135 \text { billion with effect from September and until the } \\
\text { end of the year. }\end{array}$ \\
\hline 28-Oct-15 & SWE-QE & Repo rate decision & $\begin{array}{l}\text { The Executive Board decided to extend the government bond } \\
\text { purchasing program to a total of SEK } 200 \text { billion. }\end{array}$ \\
\hline 21-Apr-16 & SWE-QE & Repo rate decision & $\begin{array}{l}\text { The Executive Board decided to extend the government bond } \\
\text { purchasing program to a total of SEK } 245 \text { billion. }\end{array}$ \\
\hline
\end{tabular}




\section{Table 6. Changes on Bond Yields on Swedish Riksbank Asset Purchase Announcement Days}

\begin{tabular}{|c|c|c|c|c|c|c|}
\hline Program & Date & 10y Yield & Expectations & Term Premium & $\begin{array}{c}\text { Global Term } \\
\text { Premium }\end{array}$ & $\begin{array}{l}\text { Country-Specific } \\
\text { Term Premium }\end{array}$ \\
\hline \multicolumn{7}{|c|}{ Panel A: Sweden } \\
\hline \multirow{14}{*}{ SWE-QE } & 12-Feb-15 & $-15.1 *$ & $-13.5 * *$ & -1.6 & 0.7 & -2.3 \\
\hline & & $(0.02)$ & $(0.01)$ & $(0.32)$ & $(0.65)$ & $(0.14)$ \\
\hline & 18-Mar-15 & $-12.7^{*}$ & $-7.2^{*}$ & -5.5 & $-5^{*}$ & -0.5 \\
\hline & & (0.03) & $(0.04)$ & $(0.06)$ & (0.03) & $(0.41)$ \\
\hline & 29-Apr-15 & 13.2 & 6.4 & 6.7 & 7.7 & -1 \\
\hline & & $(0.97)$ & $(0.95)$ & $(0.96)$ & $(0.98)$ & $(0.31)$ \\
\hline & 2-Jul-15 & $-16.9 * *$ & $-13.3^{* *}$ & -3.6 & -0.4 & -3.2 \\
\hline & & $(0.01)$ & $(0.01)$ & (0.13) & $(0.46)$ & $(0.08)$ \\
\hline & 28-Oct-15 & -1.8 & 0.9 & -2.7 & 2.4 & $-5.1 *$ \\
\hline & & $(0.40)$ & $(0.64)$ & $(0.20)$ & $(0.83)$ & (0.03) \\
\hline & 21-Apr-16 & 13.9 & 3.2 & 10.6 & 6.7 & 4 \\
\hline & & $(0.98)$ & $(0.84)$ & (0.99) & $(0.98)$ & $(0.95)$ \\
\hline & Average & -3.2 & -3.9 & 0.7 & 2 & -1.3 \\
\hline & & $(0.30)$ & $(0.15)$ & $(0.62)$ & $(0.81)$ & $(0.26)$ \\
\hline \multicolumn{7}{|c|}{ Panel B: Average Ex-Sweden } \\
\hline \multirow{14}{*}{ SWE-QE } & 12-Feb-15 & 0.9 & -0.6 & 1.6 & 0.7 & 0.9 \\
\hline & & $(0.62)$ & $(0.44)$ & $(0.76)$ & $(0.65)$ & $(0.94)$ \\
\hline & 18-Mar-15 & -8.3 & -3.8 & $-4.5^{*}$ & $-4.7^{*}$ & 0.2 \\
\hline & & $(0.05)$ & $(0.12)$ & $(0.04)$ & (0.03) & $(0.63)$ \\
\hline & 29-Apr-15 & 11.7 & 4.4 & 7.3 & 7.2 & 0.1 \\
\hline & & $(0.98)$ & $(0.92)$ & $(0.98)$ & $(0.98)$ & $(0.61)$ \\
\hline & 2-Jul-15 & -1.5 & -1.6 & 0.1 & -0.4 & 0.4 \\
\hline & & $(0.40)$ & $(0.30)$ & $(0.54)$ & $(0.46)$ & $(0.81)$ \\
\hline & 28-Oct-15 & 8.1 & 4.6 & 3.5 & 2.2 & 1.3 \\
\hline & & $(0.94)$ & (0.93) & (0.91) & $(0.83)$ & $(0.98)$ \\
\hline & 21-Apr-16 & 8.9 & 3.5 & 5.5 & 6.2 & -0.7 \\
\hline & & (0.95) & $(0.88)$ & (0.96) & (0.98) & (0.09) \\
\hline & Average & -0.6 & -0.6 & $\mathrm{o}$ & -0.8 & 0.8 \\
\hline & & $(0.50)$ & $(0.45)$ & $(0.54)$ & $(0.38)$ & $(0.95)$ \\
\hline
\end{tabular}

Note: $\left({ }^{* * *}\right),\left({ }^{* *}\right)$, and $\left({ }^{*}\right)$ indicate coefficient significantly different from zero at the $1 \%, 5 \%$ and $10 \%$ level, respectively. Average Ex-Sweden indicates the average change on bond yields across the countries in our study with the exception of Sweden. 


\section{Table 7. SNB Asset Purchase and Reserve Expansion Announcements}

\begin{tabular}{|c|c|c|c|}
\hline Date & Program & Event & Description \\
\hline 12-Mar-09 & SWI-QE & $\begin{array}{c}\text { Monetary Policy } \\
\text { Assessment }\end{array}$ & $\begin{array}{l}\text { The SNB announces it will buy Swiss franc bonds issued by private } \\
\text { sector borrowers and purchase foreign currency on the foreign } \\
\text { exchange markets. }\end{array}$ \\
\hline 3-Aug-11 & SWI-QE & Press release & $\begin{array}{l}\text { Target range for three-month CHF LIBOR lowered to } 0 \text { to } 25 \text { bps. In } \\
\text { addition, banks' sight deposits at the SNB will be expanded from } \\
\text { CHF } 30 \text { billion to CHF } 80 \text { billion. }\end{array}$ \\
\hline 10-Aug-11 & SWI-QE & Press release & $\begin{array}{l}\text { Banks' sight deposits at the SNB will rapidly be expanded from } \\
\text { CHF } 80 \text { billion to CHF } 120 \text { billion. }\end{array}$ \\
\hline 17-Aug-11 & SWI-QE & Press release & $\begin{array}{l}\text { Banks' sight deposits at the SNB will immediately be expanded from } \\
\text { CHF } 120 \text { billion to CHF } 200 \text { billion. }\end{array}$ \\
\hline
\end{tabular}


Table 8. Changes on Bond Yields on SNB Asset Purchase and Reserve Expansion
Announcements Days

\begin{tabular}{|c|c|c|c|c|c|c|}
\hline Program & Date & 10y Yield & Expectations & Term Premium & $\begin{array}{l}\text { Global Term } \\
\text { Premium }\end{array}$ & $\begin{array}{l}\text { Country-Specific } \\
\text { Term Premium }\end{array}$ \\
\hline \multicolumn{7}{|c|}{ Panel A: Switzerland } \\
\hline \multirow{10}{*}{ SWI-QE } & 12-Mar-09 & -5.6 & $-10.6^{* *}$ & 5 & -0.5 & 5.5 \\
\hline & & (0.09) & $(0.01)$ & (0.94) & (0.41) & (0.97) \\
\hline & 3-Aug-11 & -1.8 & -3.2 & 1.4 & -0.2 & 1.6 \\
\hline & & (0.35) & (0.11) & $(0.71)$ & (0.50) & (0.74) \\
\hline & 10-Aug-11 & -5.5 & -3.8 & -1.7 & -1.1 & -0.6 \\
\hline & & (0.10) & (0.09) & $(0.28)$ & (0.30) & (0.41) \\
\hline & 17-Aug-11 & $-20.3^{* *}$ & $-5.6^{*}$ & $-14.7^{* *}$ & $-8.9 * *$ & $-5.8^{*}$ \\
\hline & & $(0.00)$ & (0.04) & $(0.00)$ & $(0.00)$ & (0.03) \\
\hline & Average & $-8.3^{*}$ & $-5.8^{*}$ & -2.5 & -2.7 & 0.2 \\
\hline & & $(0.04)$ & $(0.04)$ & $(0.20)$ & $(0.10)$ & $(0.54)$ \\
\hline \multicolumn{7}{|c|}{ Panel B: Average Ex-Switzerland } \\
\hline \multirow{10}{*}{ SWI-QE } & 12-Mar-09 & -4.3 & -2.3 & -2 & -0.7 & $-1.3^{*}$ \\
\hline & & $(0.22)$ & $(0.25)$ & (0.23) & (0.41) & $(0.02)$ \\
\hline & 3-Aug-11 & -6.7 & -5.6 & -1.1 & -0.2 & $-0.9^{*}$ \\
\hline & & (0.11) & $(0.07)$ & (0.35) & (0.50) & $(0.05)$ \\
\hline & 10-Aug-11 & -4.8 & -4 & -0.8 & -1.3 & 0.5 \\
\hline & & (0.19) & (0.13) & $(0.40)$ & (0.30) & $(0.85)$ \\
\hline & 17-Aug-11 & $-19.5^{* *}$ & $-8.8^{*}$ & $-10.7^{* *}$ & $-10.9 * *$ & 0.2 \\
\hline & & $(0.00)$ & (0.02) & $(0.00)$ & $(0.00)$ & (0.64) \\
\hline & Average & -8.8 & -5.2 & -3.7 & -3.3 & -0.4 \\
\hline & & $(0.05)$ & (0.08) & (0.09) & (0.10) & (0.23) \\
\hline
\end{tabular}

Note: $\left({ }^{* * *}\right),\left({ }^{* *}\right)$, and $\left({ }^{*}\right)$ indicate coefficient significantly different from zero at the $1 \%, 5 \%$ and $10 \%$ level, respectively. Average Ex-Switzerland indicates the average change on bond yields across the countries in our study with the exception of Switzerland. 


\section{REFERENCES}

Bauer, G.H. and Diez de los Rios, A. (2012): “An International Dynamic Term Structure Model with Economic Restrictions and Unspanned Risks," Bank of Canada Staff Working Paper No. 2012-5.

Bauer, M.D. and Neely, C.J. (2014): "International Channels of the Fed's Unconventional Monetary Policy," Journal of International Money and Finance, 44, 24-46.

Bauer, M.D. and Rudebusch, G. (2014): “The Signaling Channel for Federal Reserve Bond Purchases," International Journal of Central Banking, 10, 233-289.

Bauer, M.D., Rudebusch, G.D. and Wu, C. (2012): "Correcting Estimation Bias in Dynamic Term Structure Models," Journal of Business and Economic Statistics, 30, 454-467. . (2014): “Term Premia and Inflation Uncertainty: Empirical Evidence from an International Panel Dataset: Comment," American Economic Review, 104, 323-337.

Bernanke, B.S. (2011): "Testimony: Semiannual Monetary Policy Report to the Congress before the Committee on Banking, Housing, and Urban Affairs, U.S. Senate," March 1.

Bernanke, B.S. and Reinhart, V. (2004): "Conducting Monetary Policy at Very Low ShortTerm Interest Rates," American Economic Association Papers and Proceedings, 94, 85-90.

Christensen, J.H.E. and Gillian, J.M. (2016): “Does Quantitative Easing Affect Market Liquidity?” Federal Reserve of San Francisco Working Paper 2013-26.

Christensen, J.H.E. and Krogstrup, S. (2016a): “Transmission of Quantitative Easing: The Role of Central Bank Reserves," Federal Reserve of San Francisco Working Paper 2014-16.

. (2016b): “A Portfolio Model of Quantitative Easing,” Federal Reserve of San Francisco Working Paper 2016-12.

Christensen, J.H.E. and Rudebusch, G. (2012): “The Response of Interest Rates to US and UK Quantitative Easing," Economic Journal, 122, 385-414.

Cochrane, J. and Piazzesi, M. (2008): "Decomposing the Yield Curve," mimeo, University of Chicago.

Cross, M., Fisher, P. and Weeken, O. (2010): "The Bank's Balance Sheet During the Crisis," Quarterly Bulletin (Bank of England), 50, 34-42. 
Culbertson, J.M. (1957): “The Term Structure of Interest Rates,” Quarterly Journal of Economics, 71, 485-517.

Dahlquist, M. and Hasseltoft, H. (2013). "International Bond Risk Premia," Journal of International Economics, 90, 17-32.

De Rezende, R.B. (2016): “The Interest Rate Effects of Government Bond Purchases Away from the Lower Bound," Sveriges Riksbank Working Paper Series 324.

Diez de los Rios, A. (2015): “A New Linear Estimator for Gaussian Dynamic Term Structure Models," Journal of Business and Economic Statistics, 33, 282-295.

Duffee, G.R. (2011): "Information in (and not in) the Term Structure," Review of Financial Studies, 24, 2895-2934.

Gagnon, J.E., Raskin, M., Remache, J. and Sack, B.P. (2011): "The Financial Market Effects of the Federal Reserve's Large-Scale Asset Purchases," International Journal of Central Banking, 7, 3-43.

Glick, R. and Leduc, S. (2012): "Central Bank Announcements of Asset Purchases and the Impact on Global Financial and Commodity Markets," Journal of International Money and Finance, 31, 2078-2101.

(2015): "Unconventional Monetary Policy and the Dollar: Conventional Signs, Unconventional Magnitudes," Federal Reserve of San Francisco Working Paper 201518.

Goldberg, L. and Tille, C. (2009): "Macroeconomic Inter-Dependence and the International Role of the Dollar," Journal of Monetary Economics, 56, 7, 990-1003.

Gopinath, G. (2015): “The International Price System," Federal Reserve Bank of Kansas City Economic Policy Symposium.

Greenwood, R., Hanson, S.G. and Liao, G.Y. (2016): “Asset Price Dynamics in Partially Segmented Markets," mimeo, Harvard Business School.

Greenwood, R. and Vayanos, D. (2014): "Bond Supply and Excess Bond Returns," Review of Financial Studies, 27, 663-713.

Haldane, A.G., Roberts-Sklar, M., Wieladek, T. and Young, C. (2016): “QE: The Story so Far," Bank of England Staff Working Paper 624.

Hamilton, J.D. and Wu, J.C. (2012): “The Effectiveness of Alternative Monetary Policy Tools in a Zero Lower Bound Environment," Journal of Money, Credit, and Banking, 44, 346. 
Hansen, B.E. (2010): "Averaging Estimators for Autoregressions with a Near Unit Root," Journal of Econometrics, 158, 142-155.

Hellerstein, R. (2011): “Global Bond Risk Premiums," Federal Reserve Bank of New York Staff Report No. 499.

Ilmanen, A. (1995): “Time Varying Expected Returns in International Bond Markets," Journal of Finance 50, 481-506.

Jardet, C., Monfort, A. and Pegoraro, F. (2011): "Persistence, Bias, Prediction and Averaging Estimators," mimeo, Banque de France.

(2013): "No-arbitrage Near-Cointegrated VAR (p) Term Structure models, Term Premia and GDP Growth," Journal of Banking and Finance, 37, 389-402.

Joslin, S., Singleton, K.J. and Zhu, H. (2011): “A New Perspective on Gaussian DTSMs,” Review of Financial Studies, 24, 926-970.

Joyce, M.A.S., Lasaosa, A., Stevens, I. and Tong, M. (2011): “The Financial Market Impact of Quantitative Easing in the United Kingdom," International Journal of Central Banking, 7, 113-161.

Kettemann, A. and Krogstrup, S. (2014): "Portfolio Balance Effects of the Swiss National Bank's Bond Purchase Program,” Journal of Macroeconomics, 40, 132-149.

Kilian, L. (1998): "Small-Sample Confidence Intervals for Impulse-Response Functions," Review of Economics and Statistics, 80, 218-230.

Kohn, D.L. (2009): "Monetary Policy Research and the Financial Crisis: Strengths and Shortcomings," speech at the Conference on Key Developments in Monetary Economics, Washington, DC, October 9.

Kozicki, S., Santor, E. and Suchanek, L. (2015): "Large-Scale Asset Purchases: Impact on Commodity Prices and International Spillover Effects," Bank of Canada Working Paper No. 2015-21.

Kozicki, S. and Tinsley, P.A. (2001): "Shifting Endpoints in the Term Structure of Interest Rates," Journal of Monetary Economics, 47, 613-652.

Krishnamurthy, A. and Vissing-Jorgensen, A. (2011): "The Effects of Quantitative Easing on Interest Rates: Channels and Implications for Policy," Brookings Papers on Economic Activity, 2, 215-87.

Litterman, R. and Scheinkman, J.A. (1991): "Common Factors Affecting Bond Returns," Journal of Fixed Income, June, 54-61. 
Miranda-Agrippino, S. and Rey, H. (2012): "Funding Flows and Credit in Carry Trade Economies," RBA Annual Conference Volume, Reserve Bank of Australia.

Mirkov, N. and Sutter, B. (2011): "Portfolio Substitution Effect of Quantitative Easing," mimeo, Swiss National Bank.

Modigliani, F. and Sutch, R.C. (1966): "Innovations in Interest Rate Policy," American Economic Review, 56, 178-97.

Moon, H.R. and Perron, B. (2008): "Seemingly Unrelated Regressions," in The New Palgrave Dictionary of Economics, 1-9, edited by S.N. Durlauf and L.E. Blume.

Neely, C.J. (2015): "Unconventional Monetary Policy Had Large International Effects," Journal of Banking and Finance, 52, 101-111.

Perignon, C., Smith, D.R. and Villa, C. (2007): "Why Common Factors in International Bond Returns Are Not so Common," Journal of International Money and Finance, 26, 284-304.

Rey, H. (2013): "Dilemma not Trilemma: The Global Financial Cycle and Monetary Policy Independence," Federal Reserve Bank of Kansas City Economic Policy Symposium (2016): "International Channels of Transmission of Monetary Policy and the Mundellian Trilemma," IMF Economic Review, 64, 6-35.

Rogers, J.H., Scotti, C. and Wright, J.H. (2014): "Evaluating Asset-Market Effects of Unconventional Monetary Policy: a Multi-Country Review," Economic Policy, 29, 749-799.

Rudebusch, G.D. and Wu, T. (2008): "A Macro-Finance Model of the Term Structure, Monetary Policy and the Economy," Economic Journal, 118, 906-926.

Tobin, J. (1961): "Money, Capital, and Other Stores of Value," American Economic Review Papers and Proceedings, 51, 26-37.

(1963): “An Essay on the Principles of Debt Management," in Fiscal and Debt Management Policies, 143-218, edited by the Commission on Money and Credit, Englewood Cliffs, NJ: Prentice Hall.

Vayanos, D. and Vila, J. (2009): “A Preferred-Habitat Model of the Term Structure of Interest Rates,” NBER Working Paper No. 15487.

Wallace, N.A. (1967): "The Term Structure of Interest Rates and the Maturity Composition of the Federal Debt," Journal of Finance, 22, 301-312. 
Williams, J.L. (2011): “Unconventional Monetary Policy: Lessons from the Past Three Years," Presentation to the Swiss National Bank Research Conference, Zurich, September 23.

Wright, J.H. (2012): “What Does Monetary Policy Do at the Zero Lower Bound?" Economic Journal, 122, 447-466.

Yellen, J. (2011): "Unconventional Monetary Policy and Central Bank Communications," Speech at the U.S. Monetary Policy Forum, New York, February 25. 